\title{
The Effect of Transformational Leadership on Entrepreneurial Orientation: The Mediating Role of Organizational Learning Capability
}

\author{
Bader Obeidat ${ }^{1}$, Razan Nofal $^{1} \&$ Ra'ed Masa'deh $^{2}$ \\ ${ }^{1}$ Department of Business Management, School of Business, The University of Jordan, Amman, Jordan \\ ${ }^{2}$ Department of Management Information Systems, School of Business, The University of Jordan, Amman, \\ Jordan \\ Correspondence: Bader Obeidat, Department of Business Management, School of Business, The University of \\ Jordan, Amman, Jordan. E-mail: b.obeidat@ju.edu.jo
}

Received: June 10, 2018

Accepted: September 20, 2018

Online Published: October 29, 2018

doi:10.5539/mas.v12n11p77

URL: https://doi.org/10.5539/mas.v12n11p77

\begin{abstract}
This study aims to investigate the effect of transformational leadership on entrepreneurial orientation in Jordanian commercial banks, and whether organizational learning capability mediates the effect of transformational leadership on entrepreneurial orientation. Adopting a quantitative research design, data were collected by means of a questionnaire-based survey of employees in Jordanian commercial banks. Based on 330 usable responses, the results revealed the significant effect of transformational leadership and two of its dimensions (inspirational motivation and intellectual stimulation) on entrepreneurial orientation. Two other dimensions (idealized influence and individualized consideration) did not contribute to entrepreneurial orientation. Additionally, the results showed that transformational leadership has a significant effect on organizational learning capability, and that organizational learning capability in turn affects entrepreneurial orientation. The findings confirm that organizational learning capability fully mediates the effect of transformational leadership on entrepreneurial orientation. A number of recommendations are advanced, the most important of which is that banks should improve and develop managers' transformational attributes by training them on how to deal with employees in order to increase their entrepreneurial orientation. Banks should also consider improving their learning capability, as this plays a significant role in enhancing and supporting the effect of transformational leadership attributes on entrepreneurial orientation.
\end{abstract}

Keywords: transformational leadership, organizational learning capability, entrepreneurial orientation, Jordanian commercial banks

\section{Introduction}

Given the increasing challenges of fierce competition, economic globalization, and technological development, innovation in enterprises' products and operations became an important factor for organization success (Lin et al., 2016; Obeidat et al., 2017). To keep up with the highly changing environment, organizations need to adapt the entrepreneurial orientation behaviors such as innovativeness, proactiveness, and risk taking (Kraus, 2013). The banking environment is considered highly competitive, particularly in terms of creating new products and services, and rapid changes in customer demands have created growing competition in the sector (Al-Swidi and Al-Hosam, 2012). Therefore, banks automated and developed their functions and operations and used internet and mobile applications to offer innovative products and services to the customers. To improve their entrepreneurial behaviors in the market and their performance, banks have had to focus on fostering and enhancing their intellectual capital through transformational leadership and moving toward knowledge and learning as leaders are accountable in achieving strategic organization's goals and for producing the best products with efficient resource utilization (Madanchian et al., 2016; Masa'deh et al., 2015; Hashim et al., 2018). For those reasons, it is important to examine the effect of transformational leadership on organizational learning capability and entrepreneurial orientation. Many studies have examined the effects of transformational leadership on entrepreneurial orientation (e.g. Arham et al., 2015; Afsar et al., 2017; Dzomonda et al., 2017), but only a few have investigated the effect of transformational leadership on organizational learning capability (Imamoglu et al., 
2015; Alsabbagh and Alkhalil, 2016; Elshanti, 2017), or of organizational learning capability on entrepreneurial orientation (Altinay et al., 2016; Vasconcelos et al., 2016). While these studies tested the reciprocal relationship between the two variables, the present study bridges a gap by examining the mediating role of organizational learning in how transformational leadership affects entrepreneurial orientation.

As banks face strong competition, they must be able to make major changes that include increasing their levels of innovativeness and proactiveness by developing their leadership, employee learning and knowledge sharing and by promoting a creative culture. In Jordan, banking is seen as a significant economic sector, contributing $11.6 \%$ of GDP in 2011 (CSR Watch Jordan, 2014) and banking sector including insurance and real-estate sector contributed $18.82 \%$ of GDP as of mid-2015, $20 \%$ as of mid-2016 and $22.3 \%$ as of the first quarter in 2018 (Department of statistics, 2018). The number of banks operating reached 25 at the end of 2015; 16 of them were Jordanian banks and 9 are foreign banks (Banking Sector Report, 2015). Although the income of 11 Jordanian banks increased noticeably in the first half of 2013, their rate of growth is declining because of political issues in the Middle East (Banking Sector Report, 2013). Eight of Jordanian banks, reported an increase in net income during the first nine months of 2015, during the period Arab Bank and the Housing bank for trade continued to report the largest net income of JOD 325.43 million and JOD 93.08 million respectively. While Jordan commercial bank, and Invest bank recorded the highest growth in net income of $165 \%$, and $41.49 \%$ respectively (Banking Sector Report, 2015). This environment requires banks to enhance their entrepreneurial orientation-that is, adopting an entrepreneurial approach by creating new products and services and innovative strategies (Al Azmi et al., 2012; Mahmood and Hanafi, 2013) that will give them a competitive advantage. The first step in improving the entrepreneurial orientation is to develop and foster leadership by renewing the work culture. Transformational leadership encourages employees to alter their behaviors and principles in support of entrepreneurial activities (Muchran and Muchran, 2017), and banks have altered their operations and behaviors in recent times to accommodate new learning tasks. Jordanian commercial banks were considered a suitable population in which to study the effect of transformational leadership on entrepreneurial orientation through organizational learning capability. Accordingly, this research is conducted to answer the following question, how transformational leadership affects entrepreneurial orientation as mediated by organizational learning capability?

This paper is organized as follows: the first section sets the context of the need to study the influence of transformational leadership on entrepreneurial orientation as mediated by organizational learning capability. The next section examines the research conceptual framework and the hypotheses. The next section indicates the research methodology, and the final section provides the main findings, recommendations for banks and research limitation and future studies.

\section{Research Framework and Hypotheses}

This research was conducted to demonstrate the effect of transformational leadership on entrepreneurial orientation through the organizational learning capability in the Jordanian commercial banks, where this sector is highly important and competitive.

\subsection{Operational Definitions}

The following section elaborates operational definitions for the study variables and their dimensions based on previous studies of transformational leadership, entrepreneurial orientation and organizational learning capability.

\subsubsection{Transformational Leadership (Independent Variable)}

Transformational leadership refers to the leaders who inspire followers to work toward common goals, define an attractive vision and goals, challenge employees to achieve them, build trust and confidence, and motivate employees to think and solve problems in new ways. This has been measured by reference to the dimensions of idealized influence, inspirational motivation, intellectual stimulation and individualized consideration. Idealized influence is defined in terms of a leader's ability to encourage employees to believe in their abilities to achieve defined goals, act as a role model, focus on ethics, show pride and build respect and mutual trust. Inspirational motivation can be defined as the process of defining an appealing and attractive vision, challenging employees to achieve them, and encourage them to do more than expect. Intellectual stimulation refers to leaders who inspire and motivate employees to rethink in new ways to solve existing problems, welcome new ideas and ways to do tasks and support the innovation and creativity and change of their employees. Finally, individualized consideration refers to leaders who show concern for their individual needs, assign tasks and provide resources according to their abilities, and focus on employees' development.

The questionnaire used in the present study explored 17 elements of transformational leadership; the scale was 
adapted from a study by Bell III et al. (2016). The version of the multifactor leadership questionnaire (MLQ) developed and used by Bass and Avolio (1994) to evaluate a variety of leadership types from transformational to passive leadership behavior includes 45 elements. Table 1 shows the MLQ used to assess transformational leadership.

Table 1. Transformational leadership dimensions

\begin{tabular}{|c|c|c|c|}
\hline \multicolumn{4}{|c|}{ Transformational leadership } \\
\hline Dimensions & No & Measurements & References \\
\hline \multirow[t]{6}{*}{ Idealized Influence } & 1 & $\begin{array}{l}\text { Manager instills pride in others for being } \\
\text { associated with him. }\end{array}$ & \multirow[t]{6}{*}{ Bell IIIet al. (2016) } \\
\hline & 2 & $\begin{array}{l}\text { Manager goes beyond self-interest for the good of } \\
\text { the group. }\end{array}$ & \\
\hline & 3 & $\begin{array}{l}\text { Manager acts in ways that build others' respect for } \\
\text { him. }\end{array}$ & \\
\hline & 4 & $\begin{array}{l}\text { Manager talks about the most important values and } \\
\text { beliefs. }\end{array}$ & \\
\hline & 5 & $\begin{array}{l}\text { Manager considers the moral and ethical } \\
\text { consequences of decisions. }\end{array}$ & \\
\hline & 6 & $\begin{array}{l}\text { Manager emphasizes the importance of having a } \\
\text { collective sense of mission. }\end{array}$ & \\
\hline \multirow[t]{4}{*}{$\begin{array}{l}\text { Inspirational } \\
\text { Motivation }\end{array}$} & 7 & $\begin{array}{l}\text { Manager articulates a compelling vision of the } \\
\text { future. }\end{array}$ & \multirow[t]{4}{*}{ Bell IIIet al. (2016) } \\
\hline & 8 & $\begin{array}{l}\text { Manager talks enthusiastically about what needs } \\
\text { to be accomplished. }\end{array}$ & \\
\hline & 9 & Manager talks optimistically about the future. & \\
\hline & 10 & $\begin{array}{l}\text { Manager expresses confidence that goals will be } \\
\text { achieved. }\end{array}$ & \\
\hline \multirow[t]{4}{*}{$\begin{array}{l}\text { Intellectual } \\
\text { Stimulation }\end{array}$} & 11 & $\begin{array}{l}\text { Manager gets others to look at problems from } \\
\text { many different angles. }\end{array}$ & \multirow[t]{4}{*}{ Bell IIIet al. (2016) } \\
\hline & 12 & $\begin{array}{l}\text { Manager re-examines critical assumptions to } \\
\text { question whether they are appropriate. }\end{array}$ & \\
\hline & 13 & $\begin{array}{l}\text { Manager seeks different perspectives when solving } \\
\text { problems. }\end{array}$ & \\
\hline & 14 & $\begin{array}{l}\text { Manager suggests new ways of looking at how to } \\
\text { complete assignments. }\end{array}$ & \\
\hline \multirow[t]{3}{*}{$\begin{array}{l}\text { Individualized } \\
\text { Consideration }\end{array}$} & 15 & $\begin{array}{l}\text { Manager considers each individual as having } \\
\text { different needs, abilities, and aspirations from } \\
\text { others. }\end{array}$ & \multirow[t]{3}{*}{ Bell IIIet al. (2016) } \\
\hline & 16 & Manager helps others to develop their strengths. & \\
\hline & 17 & Manager spends time teaching and coaching. & \\
\hline
\end{tabular}

\subsubsection{Organizational Learning Capability (Mediating Variable)}

Organizational learning capability is defined as the set of organizational abilities, attributes, skills that allow organization to process knowledge and experiences, transfer and store them in ways that make them available for employees. This can be measured in terms of managerial commitment, system perspective, openness and experimentation and knowledge transfer and integration. Managerial commitment refers to management recognition of the importance of organizational learning, creating an environment that promotes knowledge transfer and integration, acquiring new resources to make any changes necessary to support and promote learning in the organization. System perspective means that all individuals and departments are working together and have a shared and common goals; each one understands his/her role in achieving these goals and transferring knowledge between them. Openness and experimentation can be defined as the willingness to try new ideas, welcoming new and creative solutions to the existing problems and establishing a creative culture that allows employees to learn from past failures in order to avoid them in the future. Knowledge transfer and integration 
refers to the ability to disseminate ideas, knowledge and experiences among the organization's departments and benefiting from previous mistakes to avoid them in the future. Fifteen items were used to measure organizational learning capability, based on respondents' expressions of agreement or disagreement as set out in Table 2 below.

Table 2. Organizational learning capability dimensions

\begin{tabular}{|c|c|c|c|}
\hline \multicolumn{4}{|c|}{ Organizational Learning Capability } \\
\hline Dimensions & No & Measurements & References \\
\hline \multirow[t]{5}{*}{$\begin{array}{l}\text { Managerial } \\
\text { Commitment }\end{array}$} & 18 & $\begin{array}{l}\text { Manager involves staff in important } \\
\text { decision-making processes. }\end{array}$ & \multirow[t]{5}{*}{$\begin{array}{l}\text { Jerez-Gomez et al. } \\
(2005)\end{array}$} \\
\hline & 19 & Employee learning is an important issue. & \\
\hline & 20 & $\begin{array}{l}\text { Employee learning capability is considered a key } \\
\text { factor in this bank. }\end{array}$ & \\
\hline & 21 & $\begin{array}{l}\text { Bank's management adapts to new environmental } \\
\text { situations. }\end{array}$ & \\
\hline & 22 & $\begin{array}{l}\text { In this bank, innovative ideas that work are } \\
\text { rewarded. }\end{array}$ & \\
\hline \multirow[t]{3}{*}{ System Perspective } & 23 & $\begin{array}{l}\text { Employees have generalized knowledge regarding } \\
\text { this firm's objectives. }\end{array}$ & \multirow{3}{*}{$\begin{array}{l}\text { Jerez-Gomez et al. } \\
(2005)\end{array}$} \\
\hline & 24 & $\begin{array}{l}\text { Bank's departments are interconnected, working } \\
\text { together in a coordinated fashion. }\end{array}$ & \\
\hline & 25 & $\begin{array}{l}\text { All bank departments are well aware of their } \\
\text { contribution in achieving overall objectives. }\end{array}$ & \\
\hline \multirow[t]{3}{*}{$\begin{array}{l}\text { Openness } \\
\text { Experimentation }\end{array}$} & 26 & $\begin{array}{l}\text { Bank promotes experimentation and innovation as } \\
\text { a way of improving the work process. }\end{array}$ & \multirow[t]{3}{*}{$\begin{array}{l}\text { Jerez-Gomez et al. } \\
(2005)\end{array}$} \\
\hline & 27 & $\begin{array}{l}\text { Bank is keen to benefit from other banks } \\
\text { experience by adopting their practices and } \\
\text { techniques. }\end{array}$ & \\
\hline & 28 & $\begin{array}{l}\text { Experiences and ideas provided by advisors and } \\
\text { customers are considered a useful instrument for } \\
\text { this bank's learning. }\end{array}$ & \\
\hline \multirow[t]{4}{*}{$\begin{array}{l}\text { Knowledge Transfer } \\
\text { and Integration }\end{array}$} & 29 & $\begin{array}{l}\text { Errors and failures are always discussed and } \\
\text { analyzed in this bank. }\end{array}$ & \multirow[t]{4}{*}{$\begin{array}{l}\text { Jerez-Gomez et al. } \\
(2005)\end{array}$} \\
\hline & 30 & $\begin{array}{l}\text { Employees discuss new ideas, programs, and } \\
\text { activities that might be useful to the bank. }\end{array}$ & \\
\hline & 31 & Teamwork is preferred in this bank. & \\
\hline & & $\begin{array}{l}\text { The bank has files and database that allow what has } \\
\text { been learnt in past situations to remain valid. }\end{array}$ & \\
\hline
\end{tabular}

\subsubsection{Entrepreneurial Orientation (Dependent Variable)}

Entrepreneurial orientation is the ability of the organization to create new products and services, adopt new technologies and innovative strategies, seek new market opportunities and invest in risky projects with high return. Entrepreneurial orientation is measured on three dimensions (innovativeness, proactiveness and risk taking). Innovativenessis the willingness of the organization to be the first to create new products and services develop new processes and practices and use new technologies. Proactiveness refers to predicting and seizing new market opportunities, providing new products and services ahead of one's competitors, responding to competitors actions and being the first in fulfilling market needs. Risk taking refers to a firm's willingness to deploy its resources in new projects to achieve high benefits and returns despite a high possibility of failure. The 14 items used to measure entrepreneurial orientation required respondents to agree or disagree, based on Wolff et al. (2015) and referring to previous work by Miller (1983) and Covin and Slevin (1989) as described in Table 3 below. 
Table 3. Entrepreneurial orientation dimensions

\begin{tabular}{|c|c|c|c|}
\hline \multicolumn{4}{|c|}{ Entrepreneurial Orientation } \\
\hline Dimensions & No & Measurements & References \\
\hline \multirow[t]{5}{*}{ Innovativeness } & 33 & $\begin{array}{l}\text { The bank is the first provider of new products and } \\
\text { services for clients. }\end{array}$ & \multirow[t]{5}{*}{ Wolff et al. (2015) } \\
\hline & 34 & Bank always develops new processes. & \\
\hline & 35 & Bank emphasizes on research and development. & \\
\hline & 36 & Bank encourages people to think in novel ways. & \\
\hline & 37 & $\begin{array}{l}\text { Bank is willing to try new ways of doing things } \\
\text { and seek novel solutions. }\end{array}$ & \\
\hline \multirow[t]{5}{*}{ Proactiveness } & 38 & Bank is the first to identify clients' needs. & \multirow[t]{5}{*}{ Wolff et al. (2015) } \\
\hline & 39 & Bank pursues market opportunities. & \\
\hline & 40 & Bank initiates actions to deal with competitors. & \\
\hline & 41 & $\begin{array}{l}\text { Bank initiates actions to which competitors } \\
\text { respond. }\end{array}$ & \\
\hline & 42 & $\begin{array}{l}\text { Bank introduces new products, administrative } \\
\text { techniques and operating technologies in facing } \\
\text { competition. }\end{array}$ & \\
\hline \multirow[t]{4}{*}{ Risk Taking } & 43 & $\begin{array}{l}\text { Bank's environment requires boldness to achieve } \\
\text { objectives. }\end{array}$ & \multirow[t]{4}{*}{ Wolff et al. (2015) } \\
\hline & 44 & Bank invests in high risk projects. & \\
\hline & 45 & Bank utilizes risky market opportunities. & \\
\hline & 46 & Bank experiments with new products and services. & \\
\hline
\end{tabular}

Whereas all items were measured using a five-point rating scale, rating from one: "Strongly disagree", two: "Disagree", three: "Moderately agree", four: "Agree", to five: "Strongly agree". Research theoretical model is illustrated in figure (1) which clarifies the relationship between study variables.

Independent Variable

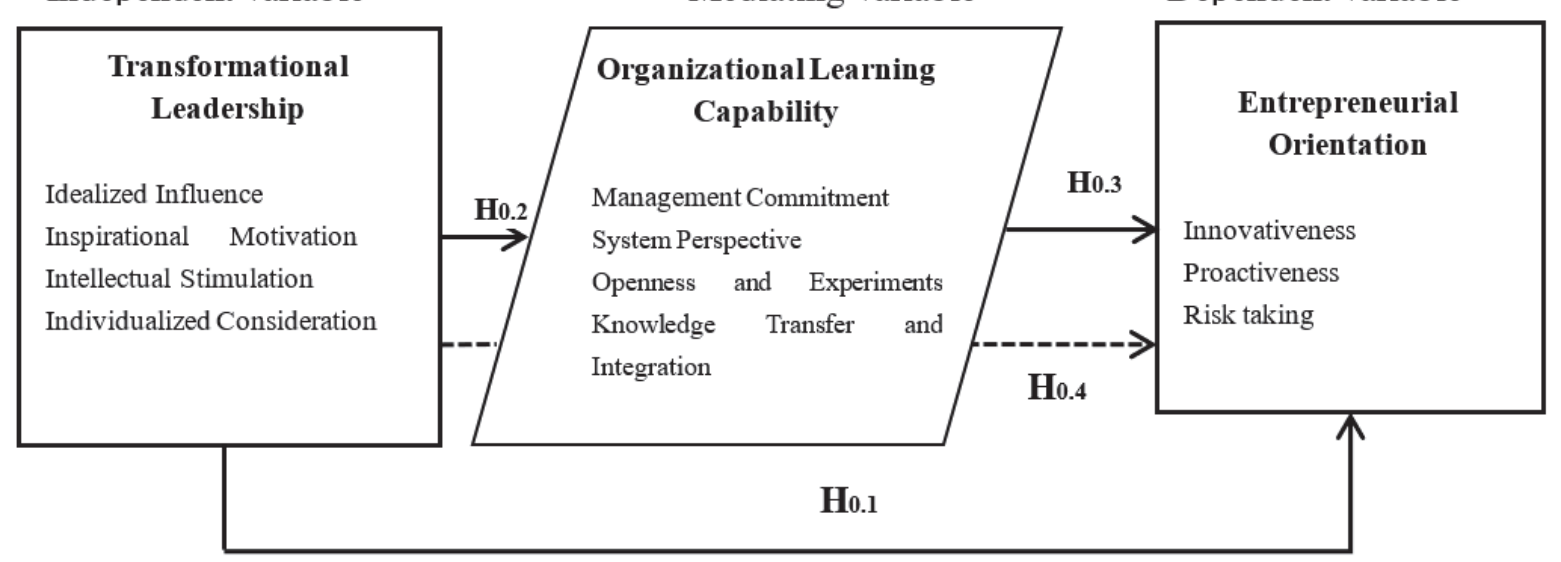

Figure 1. Research theoretical framework developed by the researchers based on studies of Öncer (2013), Alsabbagh \& Alkhalil (2016), Altinay et al. (2016)

\subsubsection{Research Hypotheses}

The principal and sub-hypotheses are set out below.

\subsubsection{First Main Hypothesis}

H0.1: There is no effect (at the level $\alpha \leq 0.05$ ) of transformational leadership on entrepreneurial orientation.

Sub-hypotheses related to H0.1 hypothesis

H01.1: There is no effect (at the level $\alpha \leq 0.05$ ) of idealized influence on entrepreneurial orientation. 
H0.1.2: There is no effect (at the level $\alpha \leq 0.05$ ) of inspirational motivation on entrepreneurial orientation.

$\mathrm{H} 0.1 .3$ : There is no effect (at the level $\alpha \leq 0.05$ ) of intellectual stimulation on entrepreneurial orientation.

H0.1.4: There is no effect (at the level $\alpha \leq 0.05$ ) of individualized consideration on entrepreneurial orientation.

\subsubsection{Second Main Hypothesis}

H0.2: There is no effect (at the level $\alpha \leq 0.05$ ) of transformational leadership on organizational learning capability.

Sub-hypotheses related to H0.2 hypothesis

H0.2.1: There is no effect (at the level $\alpha \leq 0.05$ ) of idealized influence on organizational learning capability.

H0.2.2: There is no effect (at the level $\alpha \leq 0.05$ ) of inspirational motivation on organizational learning capability.

H0.2.3: There is no effect (at the level $\alpha \leq 0.05$ ) of intellectual stimulation on organizational learning capability.

H0.2.4: There is no effect (at the level $\alpha \leq 0.05$ ) of individualized consideration on organizational learning capability.

2.1.4.3 Third Main Hypothesis

H0.3: There is no effect (at the level $\alpha \leq 0.05$ ) of organizational learning capability on entrepreneurial orientation.

Sub-hypotheses related to H0.3 hypothesis

H0.3.1: There is no effect (at the level $\alpha \leq 0.05$ ) of managerial commitment on entrepreneurial orientation.

H0.3.2: There is no effect (at the level $\alpha \leq 0.05$ ) of system perspective on entrepreneurial orientation.

H0.3.3: There is no effect (at the level $\alpha \leq 0.05$ ) of openness and experimentation on entrepreneurial orientation.

H0.3.4: There is no effect (at the level $\alpha \leq 0.05$ ) of knowledge transfer and integration on entrepreneurial orientation.

\subsubsection{Fourth Main Hypothesis}

H0.4: Organizational learning capability has no mediating role in the effect of transformational leadership on entrepreneurial orientation.

\section{Research Population, Sample, and Data Collection}

For the purposes of this research, Jordanian commercial banks were chosen as the target population because they exist in a highly changing environment that requires them to enhance their entrepreneurial activities by developing technology-based applications and electronic services (Akhisar et al., 2015). The target population includes all employees working in the 13 Jordanian commercial banks. In order to ensure representativeness, the sample from whom the data will be collected must be selected from the target population. The total number of employees working in Jordan's 13 commercial banks is 15,033 (Association of Banks in Jordan, 2015); (see Table 4).

Table 4. The number of employees working in Jordanian banks (2015)

\begin{tabular}{llll}
\hline Bank & $\begin{array}{l}\text { Total Number of } \\
\text { Employees }\end{array}$ & $\begin{array}{l}\text { Order in } \\
2015\end{array}$ & $\begin{array}{l}\text { Total percent } \\
\text { of } \\
\text { number of employees }\end{array}$ \\
\hline Arab bank & 2934 & 1 & $14.60 \%$ \\
The Housing Bank for Trade and Finance & 2363 & 2 & $11.76 \%$ \\
Cairo Amman Bank & 1614 & 3 & $8.03 \%$ \\
Bank of Jordan & 1489 & 4 & $7.41 \%$ \\
Jordan Ahli Bank & 1416 & 5 & $7.05 \%$ \\
Jordan Kuwait Bank & 1100 & 6 & $5.47 \%$ \\
Bank Al Etihad & 915 & 7 & $4.55 \%$ \\
Arab Jordan Investment Bank & 714 & 8 & $3.55 \%$ \\
Jordan Commercial Bank & 695 & 9 & $3.46 \%$ \\
Capital Bank & 575 & 10 & $2.86 \%$ \\
ABC Bank (Jordan) & 500 & 11 & $2.49 \%$ \\
Invest Bank & 461 & 12 & $2.29 \%$
\end{tabular}




\begin{tabular}{lccc} 
Societe Generale Bank & 257 & 13 & $1.28 \%$ \\
Total number working in Jordanian Commercial Banks & 15033 & & $74.81 \%$ \\
\hline
\end{tabular}

Source: (Association of Banks in Jordan, 2015)

In order to achieve and enhance sample generalizability, probability sampling (in particular, simple random sampling) would be the most appropriate method of selecting individuals from the population, where each has an equal chance of being chosen (Sekaran and Bougie, 2016). However, after encountering some difficulties in distributing the questionnaire in some banks because of their privacy policies, it was instead decided to use convenience sampling (that is, "the collection of information from members of the population who are conveniently available") (Sekaran and Bougie, 2016, p. 247). There were other reasons for using convenience sampling, including the large population, which made it difficult for the researchers to access everyone, and the limited time available for data collection (Sekaran and Bougie, 2016). The researchers ultimately distributed 378 questionnaires to banks that were accessible and agreed to receive them, without taking into consideration the size of banks. As shown in Table 5, the number of questionnaires retrieved from these banks varied according to their policies and privacy concerns.

Table 5. The research sample distribution

\begin{tabular}{ll}
\hline Bank & Number of employees included in the sample \\
\hline Arab bank & 54 \\
\hline The Housing Bank for Trade and Finance & 77 \\
\hline Cairo Amman Bank & 45 \\
\hline Bank of Jordan & 46 \\
\hline Jordan Kuwait Bank & 58 \\
\hline Bank al Etihad & 26 \\
\hline Capital Bank & 28 \\
\hline ABC Bank (Jordan) & 10 \\
\hline Total & 344
\end{tabular}

Of the 378 questionnaires that were distributed, 344 were returned, representing a return rate of $91 \%$. Fourteen questionnaires were excluded because the respondents did not answer all items on the questionnaire. As a consequence, the final number of valid questionnaires subjected to statistical analysis was 330 , representing a response rate of $87.3 \%$. Indeed, this research is based on two sources to collect data in order to test research hypotheses and achieve research objective; secondary data source includes the journals, articles, books and case studies that have been accessed through the University of Jordan website (ezlibrary.ju.edu.jo). Primary data source that represents the data obtained by the researchers for the first time, the primary data source instrument that was used by the researchers is the questionnaire that was disrupted to employees working in Jordanian commercial banks.

\section{Validity and Reliability}

Validity indicates that it measures the used instrument goodness and suitability in measuring in the study's variables. Whereas the reliability concerned about whether the measurement tool proves on the steadiness and the constancy of the measured concepts, it is also considered as the instrument mirror that reflects its precision and thoroughness (Sekaran and Bougie, 2016).

\subsection{Content and Face Validity}

Content validity refers to the extent to which the items in the questionnaire adequately address the research questions (Saunders et al., 2012). This measure is used to ensure that the dimensions and items used in the instrument adequately represent the concept (Sekaran and Bougie, 2016). To that end, the research drew on previous studies in the same area of interest to assemble questionnaire items that measured the study variables. To avoid any issues of misinterpretation, the questionnaire items were translated into Arabic. To further ensure the instrument's validity, an academic and a professional person from the same field reviewed the questionnaire to check the translation and the structure of the items.

Additionally, a pilot study was conducted to test the questionnaire items, which helped to determine whether the research instrument would work in the actual study by identifying possible problem areas that might need to be 
modified (Van-Wijk and Harrison, 2013). The pilot questionnaires were distributed to 25 participants, and the researchers contacted them to receive their feedback about any unclear items or superfluous and difficult questions. This made it possible to improve the questionnaire's effectiveness by adjusting or deleting elements and reworking or restructuring the questions where necessary.

\subsection{Construct Validity}

Construct validity is a measure of the questionnaire's validity, referring to "how well the results obtained from the use of the measure fit the theories around which the test is designed" (Sekaran and Bougie, 2016, p. 222). Construct validity is measured by factor analysis, which is a technique used to identify the dimensions of research constructs and to determine the most suitable items for each dimension. The technique of confirmatory factor analysis (CFA) was used for this purpose.CFA assesses how each item contributes to the concept (Hair et al., 2010). The aim of CFA is to examine the construct validity of the survey items in terms of their level of clarity in representing the variables under the construct (Hair et al., 2010). In other words, if the homogeneity between items of the same construct is high, there is construct validity. In addition, if the value of standardized regression weights for the latent variables is higher than 0.40 , the CFA confirms the validity of the study sentences and dimensions (Hair et al., 2010). The following figures show the construct validity of the study variables.

\begin{tabular}{cccccccc}
\hline $\mathrm{X}^{2}$ & Df & Sig & $\mathrm{X}^{2} / \mathrm{Df}$ & CFI & GFI & RMSEA & NFI \\
\hline 298.314 & 113 & 0.000 & 2.639 & .937 & .907 & 0.071 & 0.750
\end{tabular}

Standardized Regression Weights

(Group number 1-Default model)

\begin{tabular}{|c|c|c|}
\hline & & Estimate \\
\hline q6 & $<-\quad$ F1 & .668 \\
\hline $\mathrm{q} 5$ & $<-F 1$ & .665 \\
\hline $\mathrm{q} 4$ & $<--F 1$ & .657 \\
\hline$q 3$ & $<--F 1$ & .505 \\
\hline $\mathrm{q} 2$ & $<--F 1$ & .652 \\
\hline q1 & $<-F 1$ & .601 \\
\hline q10 & $<-\quad$ F2 & .825 \\
\hline q9 & $<\quad F 2$ & .801 \\
\hline q8 & $<\quad F 2$ & .800 \\
\hline $\mathrm{q} 7$ & $<--\quad F 2$ & .747 \\
\hline q14 & $<--\quad$ F3 & .791 \\
\hline q13 & $<\quad F 3$ & .761 \\
\hline $\mathrm{q} 12$ & $<--\quad F 3$ & .792 \\
\hline q11 & $<--\quad$ F3 & .746 \\
\hline q17 & $<\quad$ F4 & .778 \\
\hline q16 & $<\quad F 4$ & .805 \\
\hline q15 & $<-\quad F 4$ & .817 \\
\hline
\end{tabular}

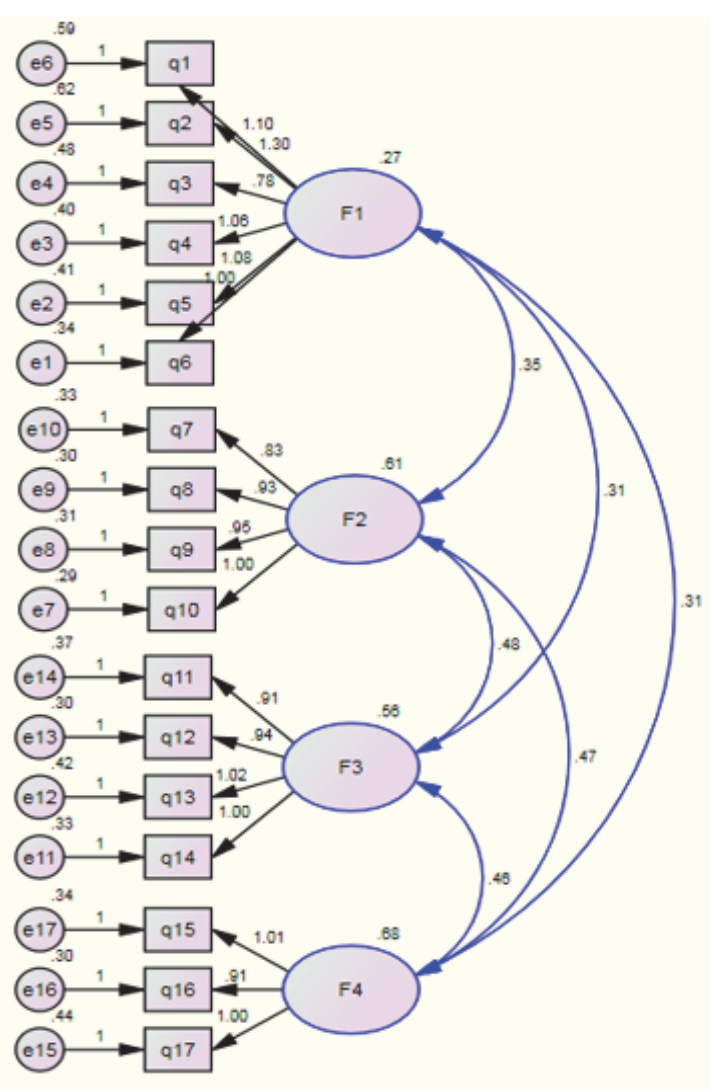

Figure 2. The construct validity of transformational leadership

Figure 2 represents the results of CFA as following:

- $\quad \mathrm{X}^{2}$ is 298.314 and it is significant at $(\alpha \leq 0.05)$. 
- Minimum discrepancy value $\left(\mathrm{X}^{2} / \mathrm{DF}\right)$ is 2.639 which indicate that the harmonization level is good; where Arbuckle (2008) declared that the harmonization level range 1 to 5 .

- Goodness of Fit Index (GFI) refers to the harmonization of quality which is 0.907 that is considered close to one (Full compatibility). On this point, the value of Comparative Fit Index (CFI) is 0.937 which is also close to one.

- The value of Root Mean Square Error of Approximation (RMSEA) is 0.071, whereas the value of Normed Fit Index (NFI) is 0.750 which is close to one. The values of Regression weight are greater than 0.40 (Hair et al., 2010, p.116). Therefore, these results emphasize and confirm the validity.

\begin{tabular}{cccccccc}
\hline $\mathrm{X} 2$ & Df & Sig & X2/Df & CFI & GFI & RMSEA & NFI \\
\hline 357.876 & 84 & 0.000 & 4.260 & 0.883 & 0.863 & 0.100 & 0.683
\end{tabular}

Standardized Regression Weights

(Group number 2 -Default model)

\begin{tabular}{|c|c|c|c|}
\hline & & & Estimate \\
\hline$q 22$ & $<-$ & F1 & .673 \\
\hline q21 & $<-$ & $\mathrm{F} 1$ & .641 \\
\hline q20 & $<-$ & $\mathrm{F} 1$ & .508 \\
\hline q19 & $<-$ & $\mathrm{F} 1$ & .524 \\
\hline q18 & $<-$ & $\mathrm{F} 1$ & .635 \\
\hline q25 & $<-$ & $\mathrm{F} 2$ & .838 \\
\hline q24 & $<-$ & $\mathrm{F} 2$ & .778 \\
\hline q23 & $<-$ & $\mathrm{F} 2$ & .732 \\
\hline q28 & $<-$ & F3 & .734 \\
\hline$q 27$ & $<-$ & F3 & .750 \\
\hline q26 & $<-$ & F3 & .791 \\
\hline q32 & $<-$ & F4 & .508 \\
\hline q31 & $<-$ & F4 & .667 \\
\hline q30 & $<$ & F4 & .760 \\
\hline q29 & $<-$ & F4 & .796 \\
\hline
\end{tabular}

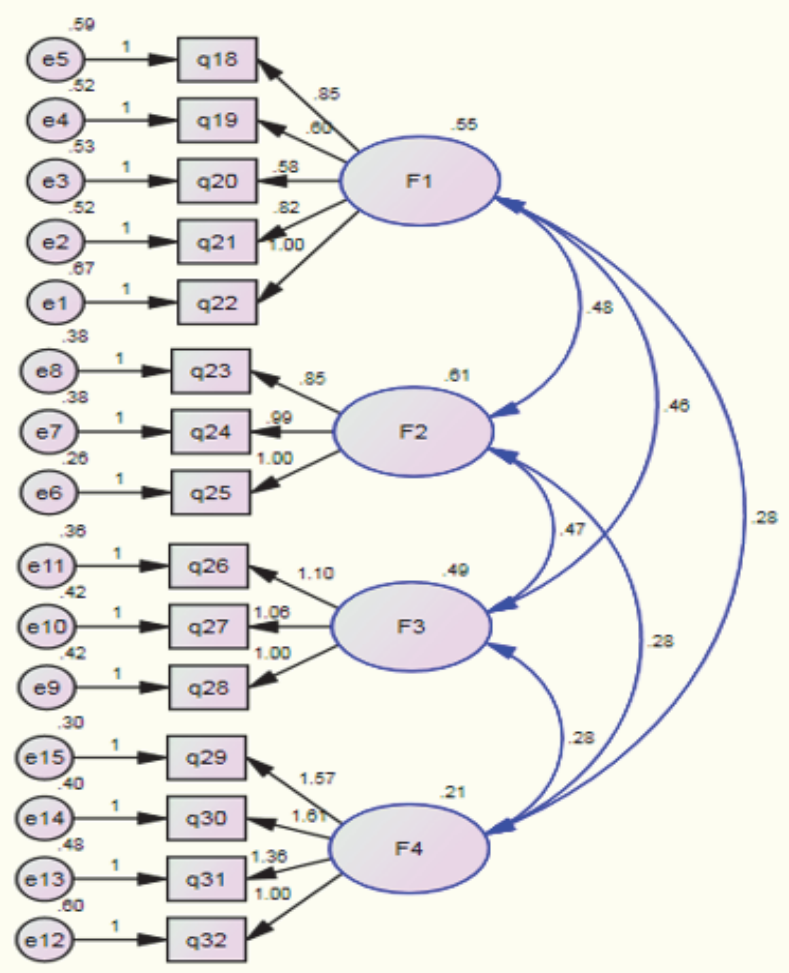

Figure 3. Construct validity of organizational learning capability

Figure 3 represents the results of CFA as following:

- $\mathrm{X}^{2}$ is 357.876and it is significant at $(\alpha \leq 0.05)$.

- Minimum discrepancy value $\left(\mathrm{X}^{2} / \mathrm{DF}\right)$ is 4.260 which indicate that the harmonization level is good; where (Arbuckle, 2008) stated that the harmonization level range 1 to 5 .

- GFI refers to the harmonization of quality which is 0.863 that is considered close to one (Full compatibility). On this point, the value of CFI is 0.883 which is also close to one.

- The value of RMSEA is 0.100 , whereas the value of NFI is 0.683 .

- The values of Regression weight are greater than 0.40 (Hair et al., 2010, p.116). These results emphasize and confirm the validity 


\begin{tabular}{cccccccc}
\hline $\mathrm{X}^{2}$ & Df & Sig & $\mathrm{X}^{2} / \mathrm{Df}$ & CFI & GFI & RMSEA & NFI \\
\hline 351.584 & 74 & 0.000 & 4.751 & .902 & .866 & 0.107 & 0.715 \\
\hline
\end{tabular}

Standardized Regression Weights:

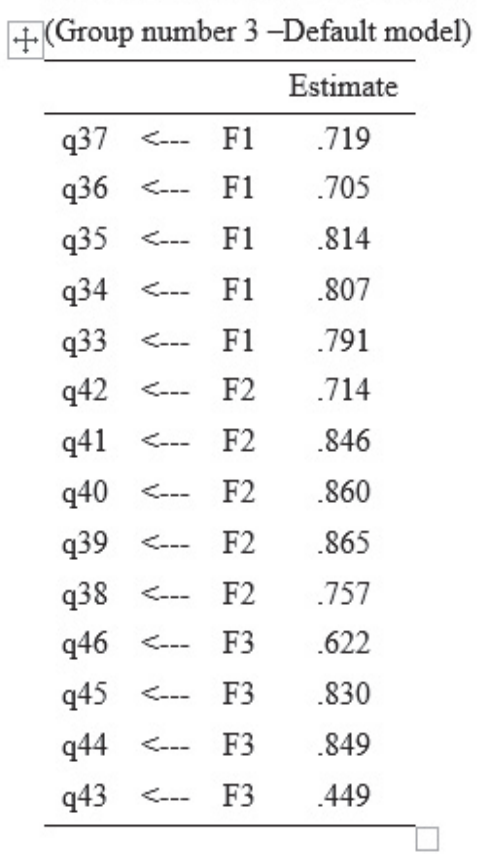

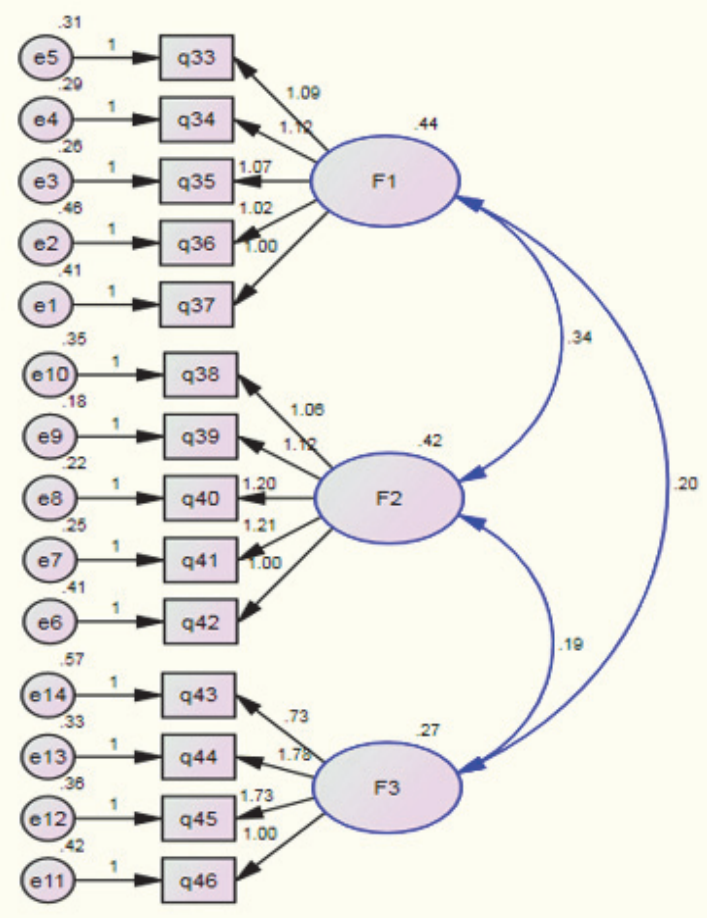

Figure 4. Construct validity of entrepreneurial orientation

Figure 4 represents the results of CFA as following:

- $\mathrm{X}^{2}$ is 351.584 and it is significant at $(\alpha \leq 0.05)$.

- Minimum discrepancy value $\left(\mathrm{X}^{2} / \mathrm{DF}\right)$ is 4.751 which indicate that the harmonization level is good; where Arbuckle, (2008) stated that the harmonization level range 1 to 5.

- GFI refers to the harmonization of quality which is 0.866 that is considered close to one (Full compatibility). On this point, the value of CFI is 0.902 which is also close to one.

- The value of RMSEA is 0.107 , whereas the value of NFI is 0.715 which is close to one.

- The values of Regression weight are greater than 0.40 (Hair et al., 2010, p.116).

These results emphasize and confirm the validity.

\subsection{Reliability of Scales}

In order to measure the consistency and homogeneity of items that belong to the same concept in the questionnaire, the internal consistency measure of inter-item consistency reliability was tested using Cronbach's alpha. Cronbach's alpha for the study sample are shown in Table 6 below. 
Table 6. Cronbach's alpha coefficient

\begin{tabular}{lll}
\hline Study construct & Number of Items & Cronbach's Alpha Values \\
\hline Transformational Leadership & 17 & 0.931 \\
\hline Idealized Influence & 6 & 0.791 \\
Inspiration Motivation & 4 & 0.871 \\
Intellectual Stimulation & 4 & 0.854 \\
Individualized Consideration & 3 & 0.839 \\
Organizational Learning Capability & 15 & 0.915 \\
\hline Managerial Commitment & 5 & 0.739 \\
System Perspective & 3 & 0.827 \\
\hline Openness and Experiment & 3 & 0.804 \\
Knowledge Transfer and Integration & 4 & 0.774 \\
\hline Entrepreneurial Orientation & 14 & 0.924 \\
Innovation & 5 & 0.876 \\
Proactiveness & 5 & 0.902 \\
Risk Taking & 4 & 0.774 \\
All variables & 46 & 0.961 \\
\hline
\end{tabular}

As the Cronbach's alpha values are greater than the acceptable level of 0.70(Sekaran and Bougie, 2016). As shown in Table 6, the variables and all of the items representing them can be said to exhibit excellent internal consistency and can therefore be considered reliable.

\section{Research Results}

\subsection{Demographic Characteristics of Respondents}

Demographic data provides the main attributes of the participating respondents which is included in the questionnaire instrument. These attributes include basic information about the respondents like age, gender, educational level, years of experience in banks and position. Table 7 shows the main attributes of the participating respondents.

Table 7. Research respondents' characteristics

\begin{tabular}{lll}
\hline Respondent's characteristics & Frequency & Percentages \\
\hline Gender & 183 & 55.5 \\
\hline Male & 147 & 44.5 \\
\hline Female & & \\
\hline Age & 87 & 26.4 \\
\hline 20 - less than 25 & 130 & 39.4 \\
\hline $25-$ less than 30 & 59 & 17.8 \\
\hline 30- less than 35 & 54 & 16.4 \\
\hline 35 and more & & \\
\hline Qualification & 264 & 80.0 \\
\hline Bachelor & 12 & 3.6 \\
\hline Diploma & 52 & 15.8 \\
\hline Master & 2 & 0.6 \\
\hline PHD & & \\
\hline Position & 229 & 69.4 \\
\hline Employee & 37 & 11.2 \\
\hline Head of Department & 36 & 10.9 \\
\hline Assistant Manager & 28 & 8.5 \\
\hline Manager & 101 & 30.6 \\
\hline Experience Tenure & 87 & 26.4 \\
\hline Less than 3 years & 51 & 15.5 \\
\hline 3 years - less than 6 years & 91 & 27.5 \\
\hline 6 years- less than 9 years &
\end{tabular}


Table 7 shows that $55.5 \%$ of respondents were males and $44.5 \%$ were females. While indicating that the number of male workers in the banking sector is slightly greater, this does not mean that male workers are preferable, as bank employees are chosen on the basis of qualifications and experience. Most of the participating employees were in the age group 25 -less than 30 years, representing $39.4 \%$ of respondents, followed by the age group 20 -less than 25 years, representing $26.4 \%$. The 35 years + age group was least represented at $16.4 \%$. This indicates that different ages are related and consistent with employees' experiences. With regard to level of education, the results indicate that a majority of respondents $80 \%$ held bachelor degrees, followed by master degree holders $15.8 \%$. Two respondents $6 \%$ held $\mathrm{PhD}$ degrees, and the remaining respondents $3.6 \%$ were diploma holders. These findings suggest that the banks' employment policies generally favor candidates with bachelor degrees or higher. They also show that banks do not necessarily focus on higher degrees, as they believe that experience is more important.

In terms of experience, the results indicate that $30.6 \%$ of respondents have less than 3 years of experience, $26.4 \%$ have 3 -less than 6 years, $15.5 \%$ have 6 -less than 9 years, and $27.6 \%$ have more than 9years of experience. The years of experience are related to the respondents age groups of the respondents; $26.4 \%$ of respondents' aged range from 20-25 years have less than 3 years of experience, this indicates that banks focus on fresh graduates not to mention that the majority of respondents were at the employees' positions not managerial positions, $27.6 \%$ of respondents have more than 9 years of experience which means that banks have a high retention rate of employees and focus on experiences. With regard to the positions, results show that employees' rate is $69.4 \%$, $11.2 \%$ head of department, $10.9 \%$ assistant mangers and $8.5 \%$ managers, because managers were not easily accessed. Employees represent the highest number of respondents 229 because of the hierarchical structure of the banks that consists of large number of employees with low number of managers to supervise and coordinate them.

\subsection{Test of Normality}

The researchers will examine the normality of data in order to assess the generalizability and representativeness of sample to the population (Ghasemi and Zahediasl, 2012). The researchers used skewness test to assess the degree of asymmetry of distribution and whether data fall between 2 and -2 , and a kurtosis test that describes the level of distribution flatness and assesses whether the data fall between 7 and -7 (West et al., 1995). The table below represents the skewness and kurtosis tests.

Table 8. Skewness and Kurtosis tests

\begin{tabular}{lcccc}
\hline \multirow{2}{*}{ Variables } & \multicolumn{2}{c}{ Skewness } & \multicolumn{2}{c}{ Kurtosis } \\
\cline { 2 - 5 } Idealized Influence & Statistic & Std. Error & Statistic & Std. Error \\
\cline { 2 - 5 } Inspirational Motivation & -.362 & 0.134 & -.314 & 0.268 \\
Intellectual stimulation & -.543 & 0.134 & -.121 & 0.268 \\
Individualized consideration & -.398 & 0.134 & -.063 & 0.268 \\
Transformational Leadership & -.542 & 0.134 & 0.154 & 0.268 \\
Managerial commitment & -.332 & 0.134 & -.377 & 0.268 \\
System perspective & -.320 & 0.134 & -.048 & 0.268 \\
Openness and experiment & -.430 & 0.134 & 0.276 & 0.268 \\
Knowledge transfer & -.448 & 0.134 & 0.118 & 0.268 \\
integration & -.420 & 0.134 & 0.507 & 0.268 \\
Organizational & & & & \\
capability & -.356 & 0.134 & 0.154 & 0.268 \\
Innovativeness & & & & \\
Proactiveness & -.929 & 0.134 & 1.707 & 0.268 \\
Risk taking & -.919 & 0.134 & 1.314 & 0.268 \\
Entrepreneurial orientation & -.095 & 0.134 & -.112 & 0.268 \\
\hline
\end{tabular}


The results in Table 8 show that the probabilities for the study variables fulfilled the tests criteria (i.e., Skewness values were lower than 2 and kurtosis values were lower than 7). Therefore, the study variables are close to the normal distribution and parametric testing can be used.

\section{Hypotheses Testing}

Testing hypotheses aims to examine whether the null hypothesis is rejected in favor of alternative hypothesis. Statistically, the null hypothesis is considered true till the statistical techniques shows the opposite (Sekaran and Bougie, 2016). The decision rule that is concerned with null hypothesis test, is when the significance level (p-value) is less than .05, the null hypothesis (H0) will be rejected and the alternative one will be accepted (HA) which indicates (a positive) effect, whereas the null hypothesis is accepted when the p-value is greater than .05.

In order to answer the research questions and to achieve the research objectives, the researchers used multiple regression to test the hypotheses to determine whether the transformational leadership in terms of dimensions has an effect on entrepreneurial orientation.

\subsection{First Main Hypothesis}

H0.1: There is no effect of transformational leadership on entrepreneurial orientation.

$\mathrm{EO}=\alpha+\beta 1 \mathrm{II}+\beta 2 \mathrm{IM}+\beta 3 \mathrm{IS}+\beta 4 \mathrm{IC}+€$.

Table 9 represents the model summary, ANOVA and coefficient tables used to test the first hypothesis, indicating the effect of transformational leadership on the dependent variable (entrepreneurial orientation) in terms of idealized influence, inspirational motivation, intellectual stimulation and individualized consideration.

Table 9. Multiple regression analysis for the first hypothesis

\begin{tabular}{|c|c|c|c|c|c|c|c|c|}
\hline \multirow[t]{2}{*}{ Variables } & \multicolumn{3}{|c|}{ Model summary } & \multicolumn{2}{|l|}{ ANOVA } & \multicolumn{2}{|c|}{ Coefficients (a) } & \multirow{2}{*}{$\begin{array}{l}\text { Unstandardized } \\
\text { coefficients }\end{array}$} \\
\hline & $\mathrm{R}$ & R Square & Adjusted R Square & F-value & Sig & & & \\
\hline & 0.522 & 0.272 & 0.263 & 30.42 & 0.000 & $\mathrm{~T}$ & $\begin{array}{l}\text { Sig. } \\
\text { (P-value) }\end{array}$ & Beta \\
\hline Constant & & & & & & 8.844 & 0.000 & 1.796 \\
\hline Idealized influence & & & & & & 1.742 & 0.082 & 0.132 \\
\hline Inspirational motivation & & & & & & 2.862 & 0.004 & 0.186 \\
\hline Intellectual stimulation & & & & & & 2.715 & 0.007 & 0.164 \\
\hline Individualized consideration & & & & & & 0.732 & 0.464 & 0.037 \\
\hline
\end{tabular}

\section{The Dependent Variable is EO}

It can be seen from the results in table (9) that the multiple correlation coefficient $\mathrm{R}=0.522$ indicates that there is a positive correlation between independent variables and dependent variable. Also, the value of $R^{2}=0.272$. This means that idealized influence, intellectual stimulation, inspirational motivation and individualized consideration can account $27.2 \%$ of the variation of the entrepreneurial orientation. Furthermore, it is noticed that the value of adjusted $R^{2}$ is very close to the value of $R^{2}$. If the adjusted $R^{2}$ is excluded from $R^{2}(0.272-0.263)=0.009$. This little shrinking 0.009 means that if the model has been fitted when the whole population participates in the study, the higher variance in the outcome will be 0.009 .

Also, the table above shows the probability of F-value and it is significant at 0.05 , which indicates that transformational leadership has a significant effect on entrepreneurial orientation at $(\alpha \leq 0.05)$. Accordingly, the first main hypothesis is rejected and the alternative is accepted. Referring to the coefficient table; the sig-value of idealized influence is 0.082 and it is not significant at $(\alpha \leq 0.05)$ and the t-calculated is 1.742 and it is lower than the t-tabulated 1.96. This indicates that the idealized influence has no significant effect on the entrepreneurial orientation at $(\alpha \leq 0.05)$. Therefore, the first null sub hypothesis is accepted and the alternative is rejected.

Referring to the coefficient table; the sig-value of inspirational motivation is 0.004 and it is significant at ( $\alpha \leq$ 0.05 ) and the t-calculated is 2.862 and it is higher than the t-tabulated 1.96. This indicates that the inspirational motivation has a significant effect on the entrepreneurial orientation at $(\alpha \leq 0.05)$. Therefore, the second null sub hypothesis is rejected and the alternative is accepted. Referring to the coefficient table; the sig-value of intellectual stimulation is .007 and it is significant at $(\alpha \leq 0.05)$ and the t-calculated is 2.715 and it is higher than the $t$-tabulated 1.96. This indicates that the intellectual stimulation has a significant effect on the entrepreneurial 
orientation at $(\alpha \leq 0.05)$. Therefore, the third null sub hypothesis is rejected and the alternative is accepted. Referring to the coefficient table; the sig-value of individualized consideration is 0.464 and it is not significant at $(\alpha \leq 0.05)$ and the t-calculated is .732 and it is lower than the t-tabulated (1.96). This indicates that the individualized consideration has no significant effect on the entrepreneurial orientation at $(\alpha \leq 0.05)$. Therefore, the fourth null sub hypothesis is accepted and the alternative is rejected.

Table 10. Results of testing the sub hypotheses for the first main hypothesis

\begin{tabular}{l}
\hline Sub Hypotheses \\
\hline H01.1: There is no effect of Idealized influence on entrepreneurial orientation.
\end{tabular}

Accordingly, the formula of this model will be formulated as below:

$\mathrm{EO}=1.796+\mathrm{II}(0.132)+\mathrm{IM}(0.186)+\mathrm{IS}(0.164)+\mathrm{IC}(0.037)+€$.

The results of the first main hypothesis indicate that transformational leadership has a significant effect on the entrepreneurial orientation of commercial banks, which concurs with previous studies (Chung-Wen, 2008; Öncer, 2013; Arham, 2014; Muchiri and McMurray, 2015) demonstrating that the level of development and success of entrepreneurial orientation relates to the presence of transformational leaders. The explanation for this finding may relate to the fact that transformational leaders encourage employees to think in creative ways, generate new ideas about existing practices and products and encourage them to change. This enhances and strengthens their entrepreneurial attitudes and, as a consequence, the entrepreneurial behaviors of organizations. Roomi and Harrison (2011) also agreed about the appropriateness of transformational leadership and its important role in the entrepreneurial environment. Leaders in entrepreneurial firms use their skills to support and develop the entrepreneurial capabilities of employees, protect creative ideas that threaten the existing business model, find opportunities for the organization to exploit and combine entrepreneurship and business strategy. Leaders' ability to identify a clear and appealing vision and mission also helps employees to achieve organizational goals, and support for creativity is highly related to the entrepreneurial strategies of innovativeness, proactiveness and risk taking (Arham et al., 2015).

In relation to the sub-hypotheses, the results indicate that idealized influence has no significant effect on banks' entrepreneurial orientation. This is not consistent with other previous studies (Muchiri and McMurray, 2015; Öncer, 2013) that reported the important effect of idealized influence on entrepreneurial orientation. Although banks' leaders build trust with their employees and display charismatic characteristics, they are inefficient to affect entrepreneurial attitudes. This may refer to the trust the leaders build with their employees which gives employees more freedom when performing their tasks and doing their jobs without being told to do so. The present results also indicate that inspirational motivation has the greatest effect on entrepreneurial orientation of banks; this may refer to the bank leaders' characteristics and behaviors, where inspirational leaders challenge employees to live up to high standards, show a willingness to achieve future goals and bring meaning to the impending task(Judge and Piccolo, 2004). In addition, leaders who define a common and attractive vision for employees, set a high level of expectation for each individual and convince them of their ability to achieve their goals can encourage innovative and proactive behaviors among employees, stimulating them to develop products and services and seek market opportunities that offer customers better service.

Leaders with the intellectual stimulation characteristic are more likely to alter existing working methods, identify new problem-solving approaches for employees, modify the organizational processes and systems to have a spectacular future, entrust employees to take responsibilities and increase the level of their commitment (Boehm et al., 2015). This can build employee innovation and experimentation, which is important in promoting entrepreneurial orientation within the organization. The present findings were inconsistent with previous studies (e.g., Muchiri and McMurray, 2015; Afsar et al., 2017) showing that individualized consideration is inefficient to affect entrepreneurial orientation. This may be attributed to the mechanisms used by banks in selecting administrative leaders and the characteristics of leaders. Leaders were inefficient to consider the different needs, 
abilities and desires of each member that affect their level of empowerment and commitment to improve banks' entrepreneurial orientation.

\subsection{Second Main Hypothesis}

H0.2: There is no effect of transformational leadership on organizational learning capability.

Table 11 represents the model summary, ANOVA and coefficient tables used to test the second hypothesis, indicating the effect of transformational leadership on organizational learning capability in terms of idealized influence, inspirational motivation, intellectual stimulation and individualized consideration.

Table 11. Multiple regression analysis for the second hypothesis

\begin{tabular}{|c|c|c|c|c|c|c|c|c|}
\hline \multirow[t]{2}{*}{ Variables } & \multicolumn{3}{|c|}{ Model summary } & \multicolumn{2}{|c|}{ ANOV } & \multicolumn{2}{|c|}{ Coefficients (a) } & \multirow{2}{*}{$\begin{array}{c}\text { Unstandardized } \\
\text { coefficients } \\
\text { Beta }\end{array}$} \\
\hline & $\mathrm{R}$ & $\begin{array}{c}\mathrm{R} \\
\text { Square }\end{array}$ & $\begin{array}{l}\text { Adjusted } \\
\text { R Square }\end{array}$ & $\begin{array}{c}\text { F-valu } \\
\text { e }\end{array}$ & Sig & $\mathrm{T}$ & $\begin{array}{l}\text { Sig. } \\
\text { (P-valu }\end{array}$ & \\
\hline & .649 & .421 & .414 & 59.025 & .000 & & e) & \\
\hline Constant & & & & & & 6.857 & .000 & 1.243 \\
\hline Idealized influence & & & & & & 2.489 & .013 & .168 \\
\hline Inspirational motivation & & & & & & 2.662 & .008 & .155 \\
\hline Intellectual stimulation & & & & & & 3.705 & .000 & .200 \\
\hline $\begin{array}{l}\text { Individualized } \\
\text { consideration }\end{array}$ & & & & & & 2.804 & .005 & .125 \\
\hline
\end{tabular}

\section{The Dependent Variable is OLC}

It can be seen from the results in table 11 that the multiple correlation coefficient $\mathrm{R}=.649$ indicates that there is a positive correlation between independent variables and dependent variable. Also, the value of $R^{2}=.421$. This means that idealized influence, intellectual stimulation, inspirational motivation and individualized consideration can account $42.1 \%$ of the variation of the organizational learning capability.

Furthermore, it is noticed that the value of adjusted $\mathrm{R} 2$ is very close to the value of $\mathrm{R}^{2}$. If the adjusted $\mathrm{R} 2$ is excluded from $\mathrm{R}^{2}(.421-0.414)=0.007$. This little shrinking 0.007 means that if the model has been fitted when the whole population participates in the study, the higher variance in the outcome will be 0.007.Also, the table above shows the probability of F-value and it is significant at 0.05 , which indicates that transformational leadership has a significant effect on organizational learning capability at $(\alpha \leq 0.05)$. Accordingly, the second main hypothesis is rejected and the alternative is accepted. Referring to the coefficient table; the sig-value of idealized influence is .013 and it is a significant at $(\alpha \leq 0.05)$ and the t-calculated is $(2.489)$ and it is higher than the t-tabulated 1.96. This indicates that the idealized influence has a significant effect on the organizational learning capability at $(\alpha \leq 0.05)$. Therefore, the first null sub hypothesis is rejected and the alternative is accepted.

Referring to the coefficient table; the sig-value of inspirational motivation is 0.008 and it is significant at ( $\alpha \leq$ 0.05 ) and the t-calculated is 2.662 and it is higher than the t-tabulated 1.96. This indicates that the inspirational motivation has a significant effect on the organizational learning capability at $(\alpha \leq 0.05)$. Therefore, the second null sub hypothesis is rejected and the alternative is accepted. Referring to the coefficient table; the sig-value of intellectual stimulation is .000 and it is significant at $(\alpha \leq 0.05)$ and the t-calculated is 3.705 and it is higher than the t-tabulated 1.96. This indicates that the intellectual stimulation has a significant effect on the organizational learning capability at $(\alpha \leq 0.05)$. Therefore, the third null sub hypothesis is rejected and the alternative is accepted. Referring to the coefficient table; the sig-value of individualized consideration is .005 and it is significant at $(\alpha \leq 0.05)$ and the t-calculated is 2.804 and it is higher than the t-tabulated 1.96. This indicates that the individualized consideration has a significant effect on the organizational learning capability at $(\alpha \leq 0.05)$. Therefore, the fourth null sub hypothesis is rejected and the alternative is accepted. 
Table 12. Results of testing the sub hypotheses for the second main hypothesis

\begin{tabular}{ll}
\hline Sub Hypotheses & Result \\
\hline H0.2.1: There is no effect of idealized influence on organizational learning & Rejected \\
capability & \\
H0.2.2: There is no effect of inspirational motivation on organizational learning & Rejected \\
capability & \\
H0.2.3: There is no significant effect of intellectual stimulation on organizational & Rejected \\
learning capability. & \\
H0.2.4: There is no effect of individualized consideration on organizational & Rejected \\
learning capability &
\end{tabular}

Accordingly, the formula of this model will be formulated as below:

$\mathrm{OLC}=1.243+\mathrm{II}(.168)+\mathrm{IM}(.155)+\mathrm{IS}(.200)+\mathrm{IC}(.125)+€$.

Findings related to the second main hypothesis indicate that transformational leadership has a significant effect on organizational learning capability. This finding aligns with other previous studies (Radzi et al., 2013; Alsabbagh and Alkhalil, 2016; Imran et al., 2016) that demonstrated the importance of transformational leaders in enhancing and supporting organizational learning capabilities. This tends to support the assumption that a transformational leadership style examines, alters and guides systems, building them in ways that share and distribute knowledge through organizational learning. This style of leadership is dedicated to and encourages organizational learning, providing everything needed to face the obstacles and difficulties that might disturb this learning (García-Morales et al., 2012). This finding is also consistent with Nafei et al. (2012), who showed that transformational leaders help members to accomplish the tasks assigned to them, listen to their needs and desires, welcome and reward their new ideas to solve issues and aspire to develop employees by utilizing their powers to enhance and develop opportunities for organizational learning.

The present findings also revealed that all the dimensions that constitute transformational leadership exert a significant effect on organizational learning capability in banks. In relation to idealized influence and its effect on organizational learning capability, this may owe to the fact that transformational leaders work hard to build respect between employees, encourage their followers to utilize resources, use the available tools and methods to attain internal and external information and take responsibility for their decisions (Manshadi et al., 2014). This may also be explained by the ability of transformational leaders to encourage employees to believe in their abilities to achieve goals.

The significant effect of inspirational motivation on organizational learning capability is consistent with Radzi et al. (2013) and Manshadi et al. (2014). They argued that leaders' ability to encourage followers to participate in the future vision, mission and strategies of the organization, to achieve objectives and show a positive attitude to the future and to support creativity and openness improves learning capabilities and therefore the organization's ability to acquire new knowledge and to change. With regard to intellectual stimulation, which has the highest effect on learning capability, it seems clear that learning requires change, which in turns requires transformational leadership. Through intellectual stimulation, leaders encourage employees to solve problems in new ways and stimulate them to find new and creative solutions, prompting behavioral changes to facilitate organizational learning, encouraging the development of mental models and supporting organizational learning (Ghorbanian et al., 2016; Elshanti, 2017). The findings for the last hypothesis indicate that individualized consideration has an effect on learning capability in banks. This may indicate that leaders focus on creating a supportive environment by understanding employees' needs and helping them to fulfill those needs by delegating authority to help them to develop themselves through personal challenges. By supporting innovation, accepting new and creative ideas and showing willingness to change, leaders can create an appropriate vision for learning (Ghorbanian et al., 2016; Alsabbagh and Alkhalil, 2016).

\subsection{Third Main Hypothesis}

H0.3: There is no effect of organizational learning capability on entrepreneurial orientation.

$\mathrm{EO}=\alpha+\beta 1 \mathrm{MC}+\beta 2 \mathrm{SP}+\beta 3 \mathrm{OAE}+\beta 4 \mathrm{KTAI}+€$.

Table 13represents the model summary, ANOVA and coefficient tables used to test the third hypothesis, indicating the effect of organizational learning capability on the dependent variable (entrepreneurial orientation) in terms of managerial commitment, system perspective, openness and experimentation and knowledge transfer and integration. 
Table 13. Multiple regression analysis for the third hypothesis

\begin{tabular}{|c|c|c|c|c|c|c|c|c|}
\hline \multirow[t]{3}{*}{ Variables } & \multicolumn{3}{|c|}{ Model summary } & \multicolumn{2}{|l|}{ ANOVA } & \multicolumn{2}{|c|}{ Coefficients (a) } & \multirow{2}{*}{$\begin{array}{l}\text { Unstandardized } \\
\text { coefficients }\end{array}$} \\
\hline & $\mathrm{R}$ & R Square & Adjusted R Square & F-value & Sig & & & \\
\hline & .752 & .565 & .560 & 105.60 & .000 & $\mathrm{~T}$ & $\begin{array}{l}\text { Sig. } \\
\text { (P-va }\end{array}$ & ue) \\
\hline Constant & & & & & & 7.552 & .000 & 1.116 \\
\hline Managerial commitment & & & & & & 1.285 & .200 & .068 \\
\hline System Perspective & & & & & & 3.366 & .001 & .149 \\
\hline Openness and Experimentation & & & & & & 5.636 & .000 & .268 \\
\hline Knowledge Transfer and Integration & & & & & & 4.727 & .000 & .239 \\
\hline
\end{tabular}

\section{The Dependent Variable is EO}

It can be seen from the results in table 13 that the multiple correlation coefficient $\mathrm{R}=.752$ indicates that there is a positive correlation between independent variables and dependent variable. Also, the value of $R^{2}=.565$. This means managerial commitment, system perspective, openness and experimentation, knowledge transfer and integration can account $56.5 \%$ of the variation of the entrepreneurial orientation. Furthermore, it is noticed that the value of adjusted $\mathrm{R}^{2}$ is very close to the value of $\mathrm{R}^{2}$. If the adjusted $\mathrm{R}^{2}$ is excluded from $\mathrm{R}^{2}(.565-.560)=$ 0.005. This little shrinking 0.005 means that if the model has been fitted when the whole population participates in the study, the higher variance in the outcome will be 0.005 .

Also, the table above shows the probability of F-value and it is significant at 0.05 , which indicates that organizational learning capability has a significant effect on entrepreneurial orientation at $(\alpha \leq 0.05)$. Accordingly, the third main hypothesis is rejected and the alternative is accepted. Referring to the coefficient table; the sig-value of managerial commitment is .200 and it is not significant at $(\alpha \leq 0.05)$ and the t-calculated is 1.285 and it is lower than the t-tabulated 1.96. This indicates that the managerial commitment has no significant effect on the entrepreneurial orientation at $(\alpha \leq 0.05)$. Therefore, the first null sub hypothesis is accepted and the alternative is rejected.

Referring to the coefficient table; the sig-value of system perspective is 0.001 and it is significant at $(\alpha \leq 0.05)$ and the $\mathrm{t}$-calculated is 3.366 and it is higher than the t-tabulated 1.96. This indicates that the system perspective has a significant effect on the entrepreneurial orientation at $(\alpha \leq 0.05)$. Therefore, the second null sub hypothesis is rejected and the alternative is accepted. Referring to the coefficient table; the sig-value of openness and experiment is .000 and it is significant at $(\alpha \leq 0.05)$ and the t-calculated is 5.636 and it is higher than the t-tabulated 1.96. This indicates that the openness and experiment has a significant effect on the entrepreneurial orientation at $(\alpha \leq 0.05)$. Therefore, the third null sub hypothesis is rejected and the alternative is accepted. Referring to the coefficient table; the sig-value of knowledge transfer and integration is .000 and it is significant at $(\alpha \leq 0.05)$ and the t-calculated is 4.727 and it is higher than the t-tabulated 1.96. This indicates that the knowledge transfer and integration has a significant effect on the entrepreneurial orientation $(\alpha \leq 0.05)$. Therefore, the fourth null sub hypothesis is rejected and the alternative is accepted.

Table 14. Results of testing the sub hypotheses for the third main hypothesis

\begin{tabular}{ll}
\hline Sub Hypotheses & Result \\
\hline H0.3.1: There is no effect of managerial commitment on entrepreneurial orientation & Accepted \\
H0.3.2There is no effect of system perspective on entrepreneurial orientation & Rejected \\
H0.3.3: There is no effect of openness and experimentation on entrepreneurial orientation & Rejected \\
H0.3.4: There is no effect of knowledge transfer and integration on entrepreneurial orientation. & Rejected \\
\hline
\end{tabular}

Accordingly, the formula of this model will be formulated as below:

$\mathrm{EO}=1.116+\mathrm{MI}(.068)+\mathrm{SP}(.149)+\mathrm{OAE}(268)+\mathrm{KTAI}(.239)+€$.

The results in relation to the third hypothesis show that banks' organizational learning capability has a significant effect on entrepreneurial orientation. This indicates that innovativeness, proactiveness and risk-taking behaviors are related to banks' ability to build a learning culture for employees, acquire and transfer knowledge, create new ideas and remain open to market opportunities. This result is consistent with previous studies (Shannak 
\&Obeidat, 2012; Altinay et al., 2016; Rajagopal, 2017) confirming that organizational learning capability has a positive effect on entrepreneurial orientation. The reason underlying this effect is that organizational learning capability helps firms to enhance and develop their innovative and proactive behaviors by developing the ability to acquire and transfer new knowledge and creating new products and ideas (Aragón -Correa et al., 2007). In addition, the process of utilizing resources to train and educate employees and develop their skills is a precursor of entrepreneurial activities. Organizational learning capability supports entrepreneurial activities, offering individuals opportunities to devise and renew their practices and processes (Zahra, 2010).

With regard to the sub-hypotheses, the results for managerial commitment showed it has no effect on entrepreneurial orientation. This contrasts with the findings of Kiziloglu (2014) and Altinay et al. (2016), which implied that when management stresses the importance of learning, supports knowledge acquisition and transfer, it is more likely to influence the firm's ability to create new products and practices and to seek market opportunities. In any organization, whatever the business, management plays a fundamental role in activating entrepreneurial orientation and a learning climate by addressing any barriers or obstacles. The relation between managerial commitment and entrepreneurial orientation is positive because the latter depends mainly on the former. With regard to the mismatch between the present analysis and the results of other studies, this can be attributed to personal factors among the study participants. Moreover, the culture can contribute to this result as Arab culture tends to have a high uncertainty avoidance which means the feeling of being threatened or intimidated by unexpected situations (Hofstede,2001), this may affect employees' empowerment. The management tends to avoid uncertainty in banks, by setting rules, to maintain their financial position and avoid financial losses and risks.

Second, the results indicate that system perspective influences banks' entrepreneurial orientation. This was explained by Altinay et al. (2016), who viewed organizations as a system of shared mental models whose main task is to acquire, distribute and share knowledge. This indicates that organizational learning is more than just individual learning; instead, it has a collective nature that requires a common language to share and integrate information. As all bank members and departments are working together toward a specific goal, which relates to development and innovativeness. It is also clear that openness and experimentation has a significant effect on banks' entrepreneurial orientation. This was confirmed by Gomes and Wojhan (2017), who demonstrated that enterprises that experiment to develop products and improve management are more likely to absorb changes and to adopt new technologies and procedures. This may also reflect the openness of banks to the external environment in the search for new ideas and solutions to existing and future problems. This is likely to enhance workers' knowledge of new ideas and environmental changes related to customer products and services and to technological developments and practices.

Finally, the present results indicate that knowledge transfer and integration support banks' entrepreneurial orientation. Keskin (2006) demonstrated that methods for sharing lessons learned in organizational practices between departments and teams are a key factor in innovativeness. This may be because knowledge sharing between employees and departments is effective; banks make sure to transfer knowledge related to past failures in order to avoid mistakes, and information about new ideas and employees' experiences can be of benefit to others.

\subsection{Fourth Main Hypothesis}

H0.4: Organizational learning capability has no mediating role in the effect of transformational leadership on entrepreneurial orientation.

$\mathrm{EO}=\alpha+\beta 1 \mathrm{TL}+\beta 2 \mathrm{OLC}+€$.

Path analysis will be used to examine the mediating role of the organizational learning capability in the effect of transformational leadership on entrepreneurial orientation. Therefore, the mediating effect will discover the indirect impact of the transformational leadership on the entrepreneurial orientation in the presence of the organizational learning capability as a mediator variable. To achieve this purpose the mediator effect will be examined into two stages. The first stage is to examine the direct impact in the absence of the mediator variable. Therefore, on the one hand, if the direct impact is reduced and significant; there will be a partial mediation. On the other hand, if the direct impact is reduced and not significant; there will be a complete mediation. This method was inspired by (Baron and Kenny, 1986). The researchers used AMOS and SPSS programs to test the fourth main hypothesis (H0.4).

\subsubsection{Testing H0.4 using AMOS}

As a first stage that examine the direct impact of transformational leadership on entrepreneurial orientation as 
below:

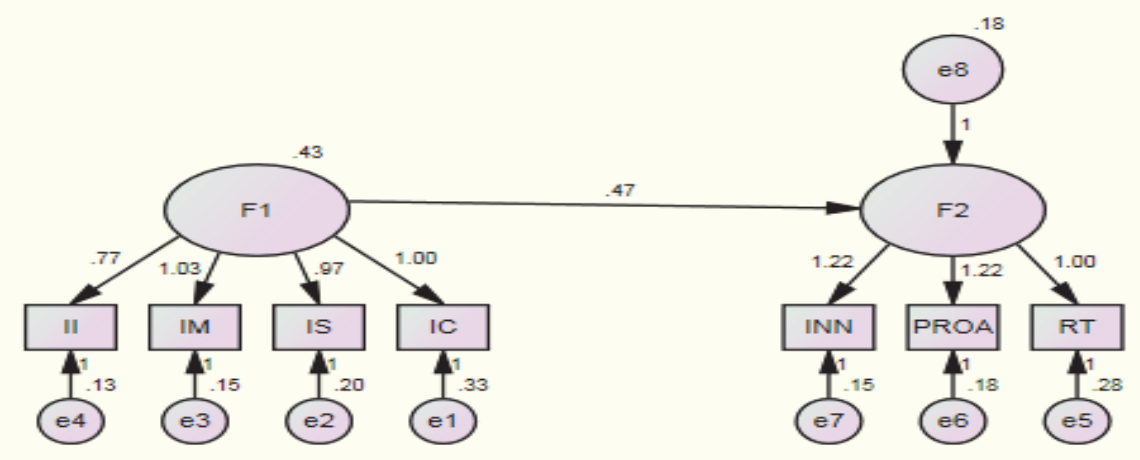

Table 15. Direct effect summary

\begin{tabular}{lllllllll}
\hline TL - EO & $\mathrm{X}^{2}$ & $\mathrm{X}^{2} / \mathrm{Df}$ & GFI & CFI & RMSEA & Probability Level & Direct Impact & Sig \\
\cline { 2 - 8 } & 25.593 & 1.968 & 0.979 & 0.990 & 0.054 & 0.019 & 0.468 & 0.000 \\
\hline
\end{tabular}

The results of the above table and diagram show that the sig-value is 0.00 and it is significant at $(\alpha \leq 0.05)$ and the value of impact is 0.468 . This implies that the transformational leadership has a significant effect on the entrepreneurial orientation. Furthermore, the results in the above reveal that the value of $X^{2}$ is 25.593 and it is significant at $(\alpha \leq 0.05)$. Also, the minimum discrepancy value $\left(\mathrm{X}^{2} / \mathrm{DF}\right)$ is 1.968 which indicate that the harmonization level is good; where Arbuckle, (2008) stated that the harmonization level range 1 to 5 . Additionally, the GFI which represents the harmonization of quality is 0.979 and this value is close to one (Full compatibility). In this regard, the value of CFI is 0.990 and it is also close to one. Furthermore, the result above shows that the value of RMSEA is 0.054 is close to zero (Hair et al., 2010). Moreover, the Average variance extracted is 0.389 which represent the variance in the dependent variable that caused by the variances in the independent variables. Accordingly, we are going to the stage two to examine the role of mediator. Therefore, to consider that the organizational learning capability plays the role of mediator the following conditions must be met. (1) The direct effect of transformational leadership on entrepreneurial orientation should become insignificant the value of effect must be decreased. (2) The direct effect of transformational leadership on organizational learning capability must be significant. (3) The direct effect of organizational learning capability on entrepreneurial orientation must be significant.

The following diagram shows the results of indirect effect:

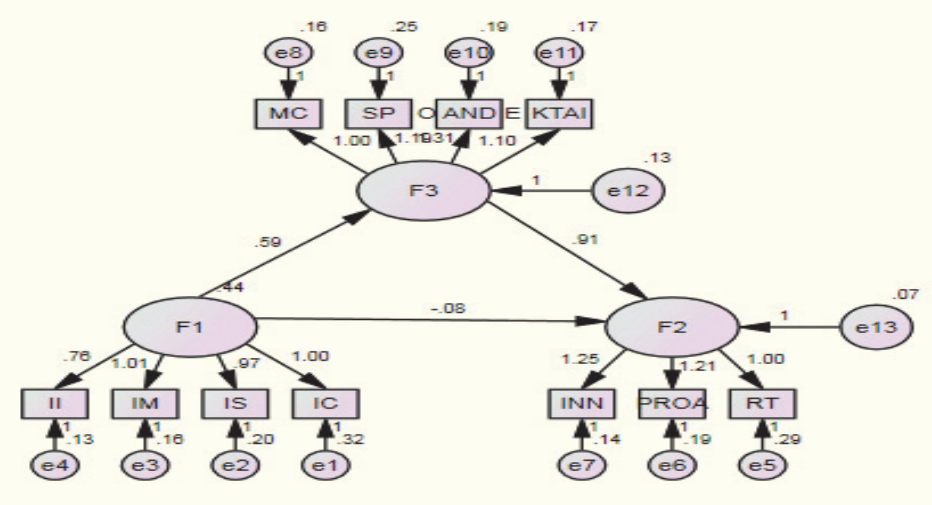


Table 16. Indirect effect summary

\begin{tabular}{|c|c|c|c|c|c|c|c|c|c|c|}
\hline & $X^{2}$ & $\mathrm{X}^{2} / \mathrm{df}$ & GFI & CFI & RMSEA & SIG & Direct Impact & Indirect Impact & Sig & C.R \\
\hline TL - OLC & 121.135 & 3.954 & 0.940 & 0.966 & 0.077 & 0.000 & 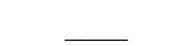 & 0.592 & 0.000 & 10.957 \\
\hline OLC- EO & & & & & & & 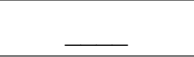 & 0.906 & 0.000 & 9.786 \\
\hline TL - EO & & & & & & & -0.077 & 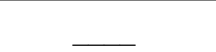 & 0.179 & -1.343 \\
\hline
\end{tabular}

The above results show that the effect of the transformational leadership on organizational learning capability is significant at 0.05 and the value of impact is 0.592 and the effect of organizational learning capability on entrepreneurial orientation is significant at 0.05 and the value of impact is 0.906 . Additionally, the effect of transformational leadership on entrepreneurial orientation is not significant at 0.05 as well as the value of impact has been decreased after taking into account the mediator variable. This indicates the organizational learning capability plays the complete mediation role. Accordingly, the total effect can be calculated as below:

$-0.077+(0.592 * 0.906)=0.459$. Furthermore, the results in the above reveal that the value of $X^{2}$ is 121.135 and it is significant at $(\alpha \leq 0.05)$. Also, the Minimum discrepancy value $\left(\mathrm{X}^{2} / \mathrm{DF}\right)$ is 3.954 which indicate that the harmonization level is good; where (Arbuckle, 2008) stated that the harmonization level range 1 to 5 . Additionally, the GFI which represent the harmonization of quality is 0.940 and this value is close to one (Full compatibility). In this regard, the value of CFI is 0.966 and it is also close to one. Furthermore, the result above shows that the value of RMSEA is 0.077 is close to zero (Hair et al., 2010, p. 116).

The researchers used AMOS and SPSS programs to test the mediating effect of organizational learning capability on transformational leadership effects on entrepreneurial orientation in order to ensure and confirm that the mediating variable plays a fully mediating role.

\subsubsection{Testing H0.4 using SPSS}

For a better understanding, the effect of transformational leadership on entrepreneurial orientation will be investigated with the absence of organizational learning capability. This effect should be statistically significant. Then, the effect of transformational leadership on entrepreneurial orientation will be investigated with the presence of organizational learning capability. To determine the level of mediation effect, if the effect of transformational leadership on entrepreneurial orientation is significant and reduced, then, organizational learning capability is partially mediating the effect of transformational leadership on entrepreneurial orientation. On the same hand, if the effect of transformational leadership is reduced but not significant. Then, organizational learning capability is fully mediating the effect of transformational leadership on entrepreneurial orientation. The effect of transformational leadership on entrepreneurial orientation is analyzed by regression analysis including Baron and Kenney's (1986) mediated regression technique as below:

Table 17. Regression analysis for mediation of TL on EO through OLC

\begin{tabular}{|c|c|c|c|c|}
\hline \multicolumn{5}{|c|}{$\mathrm{TL} \rightarrow$ OLC (Path A) } \\
\hline OLC & Coefficient & SE & $\mathrm{T}$ & $\mathrm{P}$ \\
\hline & .6432 & .0418 & 15.3840 & .0000 \\
\hline \multicolumn{5}{|c|}{ OLC $\rightarrow$ EO (Path B) } \\
\hline OLC & .7087 & .0483 & 14.6694 & .0000 \\
\hline \multicolumn{5}{|c|}{$\mathrm{TL} \rightarrow \mathrm{EO}$ (Path C) } \\
\hline \multicolumn{5}{|c|}{$\mathrm{TL} \rightarrow \mathrm{OLC} \rightarrow \mathrm{EO}$ (Path $\left.\mathrm{C}^{\prime}\right)$} \\
\hline TL & .0545 & .0480 & 1.1351 & .2571 \\
\hline
\end{tabular}

The findings above show the path of the effect of transformational leadership on organizational learning capability and entrepreneurial orientation. It has been found that transformational leadership has a significant effect on organizational learning capability where the coefficient value is 0.6432 . This can be seen at Path (A). Regarding the effect of organizational learning capability on entrepreneurial orientation, it can be argued that organizational learning capability has a significant effect on entrepreneurial orientation where the coefficient value is 0.7087 . This can be seen at Path (B). However, in order to determine whether organizational learning capability has a mediating role in the effect of transformational leadership on entrepreneurial orientation, these 
rules must be met (Baron and Kenny, 1986); the effect of transformational leadership on organizational learning capability must be significant, the effect of organizational learning capability on entrepreneurial orientation must be significant and the effect of transformational leadership on entrepreneurial orientation must be significant and the strength of the effect must be reduced.

Accordingly, table17 shows that transformational leadership has a significant effect on entrepreneurial orientation where the coefficient value is .5103 (Path C). Furthermore, this effect becomes insignificant and reduced in the presence of organizational learning capability (Path $\mathrm{C}^{\prime}$ ). Therefore, it can be postulated that organizational learning capability fully mediates the effect of transformational leadership on entrepreneurial orientation. The following table summarizes the study model:

Table 18. The mediated regression results

\begin{tabular}{cccccc}
\hline $\mathrm{R}^{2}$ & Adjusted $\mathrm{R}^{2}$ & F-Value & $\mathrm{DF} 1$ & $\mathrm{DF} 2$ & $\mathrm{P}$ \\
\hline .5562 & .5535 & 204.9004 & 2.0000 & 327.0000 & .0000 \\
\hline
\end{tabular}

The results of the mediating role analysis of organizational learning capability through the use of AMOS and SPSS indicate that organizational learning capability plays a fully mediating role between transformational leadership and entrepreneurial orientation, converting the direct effect of transformational leadership on entrepreneurial orientation into an indirect effect. This indicates that the average variance explained in the presence of organizational learning capability is higher than in the absence of it. This means that organizational learning capability enhances the transformational leadership characteristics by creating a culture that focuses on change and creativity; acquiring and transferring knowledge and experiences between bank departments and storing information to avoid previous failures; encouraging employees to create new ideas and then rewarding them; improving employees learning abilities, skills and training; and finding creative solutions for problems and experimenting with new ideas, technologies and change, as entrepreneurial orientation depends on all the dimensions of organizational learning capability. It also depends on new and innovative ideas, acquiring new knowledge and creating a culture that supports change. García-Morales et al. (2007) demonstrated that successful entrepreneurial firms have learning capabilities. In addition, studying the outer environment gives banks a great advantage, by using the acquired knowledge in creating innovation and improving the organizational structure and processes. Banks have begun to provide their customers with innovative products, this requires firms to monitor the outer environment and then convert what they have learnt into systematic knowledge (Kiziloglu, 2014).

\section{Conclusion}

This study analyzed the effect of transformational leadership on entrepreneurial orientation as mediated by organizational learning capability by collecting data from employees in Jordanian commercial banks. To create new products for customers, outperform competitors, achieve first mover status in the market and keep up to date with environmental changes, banks need to engage in entrepreneurial behaviors.

The first objective of this research was to examine the effect of transformational leadership on entrepreneurial orientation. In general, the results showed that transformational leadership has an effect on a bank's entrepreneurial orientation. This finding aligns with those from other previous studies (e.g. Afsar et al., 2017; Hashim et al., 2018) which indicated the important role played by a transformational style of leadership in enhancing a firm's entrepreneurial orientation. Transformational leaders are known for their ability to stimulate employees to achieve their goals, building trust between them, inspiring them to do more than expected and supporting them to pursue and achieve an appealing vision. Based on the results of the present analysis, it can be concluded that two dimensions of transformational leadership, inspirational motivation and intellectual stimulation, have a significant effect on banks' entrepreneurial orientation. This indicates that transformational leadership is likely to encourage employees to develop and enhance their personal performance and to exceed their own expectations, which in turn affects the entrepreneurial orientation of the banks. However, the results indicated that idealized influence and individualized consideration have no effect on banks' entrepreneurial orientation.

The second objective of the present study was to investigate the effect of transformational leadership on organizational learning capability. The findings suggest that transformational leadership has a significant effect on organizational learning capability in terms of four dimensions: idealized influence, inspirational motivation, 
intellectual stimulation and individualized consideration. These findings are consistent with those of previous studies (Radzi et al., 2013; Elshanti, 2017), and organizations with transformational leaders are thought to have a number of advantages. These leaders build relationships with employees to encourage them to work hard. They achieve success, develop their followers' performance and encourage them to upgrade their performance and to achieve group goals. Transformational leaders have a significant effect in activating learning, and implementation of knowledge; they facilitate organizational learning by advising, by identifying structures and activities and by building relationships within groups (Manshadi et al., 2014). The present results also indicate that intellectual stimulation and idealized influence are the most significant predictors of organizational learning capability in banks. This may be because managers and supervisors encourage employees to think creatively, stimulate them to find new ways of solving problems and inspire them to believe in their abilities and to deal with different situations and to learn (Elshanti, 2017).

The third objective of the present study was to examine the effect of organizational learning capability and its dimensions-managerial commitment, system perspective, openness and experimentation and knowledge transfer and integration-on the entrepreneurial orientation of commercial banks in Jordan. The results show that banks' entrepreneurial orientation is affected by their level of organizational learning capability, with the exception of managerial commitment, which has no effect on entrepreneurial orientation. These results are consistent with Altinay et al. (2016) and García-Morales et al. (2007), who indicated that firms that develop effective learning techniques are more likely to motivate entrepreneurial activities. Consistent investment in resources can improve learning capability, leading in turn to the development of entrepreneurial orientation. Organizational learning capability plays an important role in the proactive entrepreneurial engagement and development of organizations. Rajagopal (2017) demonstrated that managers who promote and support organizational learning by sharing knowledge among departments and organization are aware of the importance of learning and knowledge to the organization, accept new ideas, and motivate employees to be creative, this enables the organization to keep up to date with environmental changes.

The final objective of the present study was to examine the mediating role of organizational learning capability in transformational leadership's effect on entrepreneurial orientation. The results indicate that organizational learning capability fully mediates the effect of transformational leadership on entrepreneurial orientation, which means that organizational learning capability renders the direct effect of transformational leadership on entrepreneurial orientation insignificant. This finding confirms that organizational learning capability is an integral mechanism that leverages and enhances the effect of transformational leadership on entrepreneurial orientation by enhancing banks' abilities to create a learning culture that supports new creative ideas and solutions, knowledge acquisition and sharing of experiences internally.

\subsection{Recommendations and Implications of Findings}

The research aims at investigating the effect of transformational leadership on entrepreneurial orientation as mediated by organizational learning capability in Jordanian commercial banks. Therefore, the useful findings produced can be utilized by bank managers towards the development and implementation of practices that will lead to improve banks entrepreneurial orientation and enhance learning capabilities. Banks are suggested to improve their managers' transformational attributes; managers should be equipped to motivate and inspire employees, enhance their commitment and enthusiasm, reward creative members who think outside the box and enhance change and sharing knowledge, in order to foster and enhance their learning capabilities and the their entrepreneurial orientation. This can be done by training managers on how to deal with their followers and inspire them and encourage changes in order to improve their abilities. In addition, evaluating managers periodically and rewards them according to their performance.

Managers and leaders are participating inspirational motivation and intellectual stimulation to enhance banks entrepreneurial orientation while ignoring individualized consideration based on the respondents' points of view. Therefore, the researchers suggested that banks have to train their managers and leaders on how to deal with different employees' needs and abilities and listen to their problems, build mutual trust between employees and their managers, how to coach and monitor employees in ways that motivate their behaviors (see e.g. Al-Syaidh \& Al-Zu'bi, 2014; AlHarrasi \& AL-Lozi, 2015; AlHarrasi et al., 2016; AL-Syaidh et al., 2016; Darawsheh et al., 2016; Alkandari et al., 2017; Khalayleh et al., 2017;Abualoush et al., 2018a, 2018b; Al-dalahmeh et al., 2018; Masa'deh, et al., 2018). In addition, the findings suggested that banks should heed the importance of managerial commitment, and that managers from different levels and departments should attend training sessions, awareness and brainstorming sessions about the importance of learning for the bank. This would educate managers about the learning process and help them in supporting and adopting learning-oriented behaviors for each employee and motivating creative ideas by giving rewards for employees' new ideas and new ways to solve problems. 
With regards to the mediating effect of organizational learning capability in transformational leadership effects on entrepreneurial orientation, the findings of the study indicate that organizational learning capability does play a significant mediating role. Consequently, banks and managers should improve and enhance their learning capabilities by conducing learning sessions for employees, giving followers the chance to acquire knowledge from various sources, discussing new ideas, enhancing management practices and procedures that revolves around learning, creating a creative culture that supports innovations, using appealing encouragement techniques like brainstorming technique, and rewarding employees who think creatively and provide new solutions and ideas. These suggestions to enhance banks learning abilities affect and enhance their entrepreneurial orientation. When employees are engaged in these training and learning behaviors, the ability of managers to enhance their entrepreneurial orientation is improved and enhanced because they have a creative environment which motivates and inspires them to be creative, create new solutions and ideas and acquire and transfer new knowledge that is important to develop new products, behaviors and practices.

\subsection{Limitation of the Study}

There are some limitations about the information that has been gathered, identified and discussed in this study. The first limitation faced by the researchers was distributing the questionnaire in some banks, as they were not fully cooperative in distributing the questionnaire due to their privacy policies. Another limitation was the time. Indeed, time limitations affected a number of decisions during its implementations. Finally, there was a lack of studies that investigated the effect of organizational learning capability on entrepreneurial orientation.

\subsection{Future Research}

Based on the above results and conclusions, the researchers suggest the followings for the future studies; the future researchers could conduct this study on other sectors like telecommunications, insurance, pharmaceutical companies and small and medium sized firms that have different culture and market practices. Future studies also could examine entrepreneurial orientation from the mentioned dimensions in addition to autonomy and competitive aggressiveness aspects. Additionally, future studies could examine the effect of other types of leadership like transactional, participative and instrumental on entrepreneurial orientation.

Also, researchers called for more research on the enabling factors of applying electronic services (e.g. Masa'deh, et al., 2008, 2013a, 2013b; Karajeh \& Maqableh, 2014; Maqableh \& Karajeh, 2014; Al-Dmour et al., 2015; Almajali \& Maqableh, 2015; Kateb et al., 2015; Maqableh et al., 2015; Masa'deh, 2016; Tarhini et al., 2015; 2016, 2017a, 2017b; Almajali \& Al-Dmour, 2016; Almajali et al., 2016; Alenezi et al., 2017; Aldmour et al., 2017; Khwaldeh et al., 2017; Mikkawi \& Al-Lozi, 2017; Obeidat et al., 2017; Yassien \& Mufleh, 2017; Tarhini et al., 2018; Al-Dmour et al., 2019), hence, future studies could examine a mediating effect of variables other than organizational learning capability such as employees' empowerment and organizational culture.

\section{References}

Abualoush, S. H., Obeidat, A. M., Tarhini, A., Masa'deh, R., \& Al-Badi, A. (2018b). The role of employees' empowerment as an intermediary variable between knowledge management and information systems on employees' performance. VINE Journal of Information and Knowledge Management Systems, 48(2), 217-237.

Abualoush, S., Bataineh, K., \& Alrowwad, A. (2018a). The role of knowledge management process and intellectual capital as intermediary variables between knowledge management infrastructure and organization performance. Interdisciplinary Journal of Information, Knowledge, and Management, 13, 279-309.

Afsar, B., Badir, Y., Saeed, B., \& Hafeez, S. (2017). Transformational and transactional leadership and employee's entrepreneurial behavior in knowledge-intensive industries. The International Journal of Human Resource Management, 28(2), 307-332.

Akhisar, I., Tunay, K., \& Tunay, A. (2015). The effects of innovations on bank performance: The case of electronic banking services. Procedia- Social and Behavioral Sciences, 369-375.

Al Azmi, N., Al-Lozi, M., Al-Zu'bi, Z., \& Dahiyat, S. (2012). Patients attitudes toward service quality and its impact on their satisfaction in physical therapy in KSA hospitals. European Journal of Social Sciences, 34(2), 300-314.

Al-dalahmeh, M., Khalaf, R., \& Obeidat, B. (2018). The effect of employee engagement on organizational performance via the mediating role of job satisfaction: The case of IT employees in Jordanian banking sector. Modern Applied Science, 12(6), 17-43. 
Al-Dmour, R, Obeidat, B., \& Almajali, D. (2015). The practice of HRIS applications in business organizations in Jordan: An empirical study. 4th Scientific \& Research Conference on New Trends in Business, Management and Social Sciences (COES\&RJ-TK15/1).

Al-Dmour, R., Al Haj Dawood, E., Al-Dmour, H., \& Masa'deh, R. (2019). The effect of customer lifestyle patterns on the use of mobile banking applications in Jordan. Int. J. Electronic Marketing and Retailing, Forthcoming.

Aldmour, R., Masa'deh, R., \& Obeidat, B. (2017). Factors influencing the adoption and implementation of HRIS applications: Are they similar. International Journal of Business Innovation and Research, 14(2), 139-167.

Alenezi, H., Tarhini, A., Alalwan, A., \& Al-Qirim, N. (2017). Factors affecting the adoption of e-government in Kuwait: A qualitative study. Electronic Journal of e-Government, 15(2), 84-102.

AlHarrasi, J., \& AL-Lozi, M. (2015). The role of innovation management and technological innovation on organizational effectiveness. 4th Scientific \& Research Conference on New Trends in Business, Management and Social Sciences (COES\&RJ-TK15/1), Istanbul, Turkey.

AlHrassi, J., Al-Lozi, M., \& Irtaimeh, H. (2016). The impact of management innovation and technological innovation on organizational effectiveness: An empirical study from managerial staff perspective in Sultan Qaboos University. Journal of Social Sciences (COES\&RJ-JSS), 5(3), 309-339.

Alkandari, A., Masa'deh, R., \& Al-Lozi, M. (2017). Knowledge management and its role on organizational crisis management: A literature review. Journal of Social Sciences (COES\&RJ-JSS), 6(4), 833-850.

Almajali, D., \& Al-Dmour, R. (2016). The role of information technology in motivating students to accept e-learning adoption in universities: A case study in Jordanian universities. Journal of Business \& Management (COES\&RJ-JBM), 4(1), 36-46.

Almajali, D., \& Maqableh, M. (2015). Assessing the digital divide status of the Jordanian telecentre. International Journal of Communications, Network and System Sciences, 8(11), 428-439.

Almajali, D., Masa'deh, R., \& Al-Lozi, M. (2016). Determinants of the actual use of e-learning systems: An empirical study on Zarqa University in Jordan. Journal of Social Sciences (COES\&RJ-JSS), 5(2), 172-200.

Alsabbagh, M., \& Alkhalil, A. (2016). The impact of leadership styles on organizational learning (an empirical study on the education sector in Damascus city). International Journal of Academic Research in Business and Social Sciences, 6(5), 197-216.

Al-Swidi, A., \& Al-Hosam, A. (2012). The effect of entrepreneurial orientation on the organizational performance: A study on the Islamic banks in Yemen using the partial least squares approach. Arabian Journal of Business and Management Review (Oman Chapter), 2(1), 73.

Al-Syaidh, N., \& Al-Zu'bi, Z. (2014). Transformational leadership and its impact on the effectiveness of employees' behavior in the public and private Jordanian hospitals. Jordan Journal of Business Administration, 11(1), 23-57.

AL-Syaidh, N., Al-Lozi, M., \& AlHarrasi, J. (2016). Transformational leadership and its role on the effectiveness of employees' behavior: A theoretical study. Journal of Business \& Management (COES\&RJ-JBM), 4(1), 14-35.

Altinay, L., Madanoglu, M., De Vita, G., Arasli, H., \& Ekinci, Y. (2016). The interface between organizational learning capability, entrepreneurial orientation, and SME Growth. Journal of Small Business Management, 54(3), 871-891.

Aragón-Correa, J., García-Morales, V., \& Cordón-Pozo, E. (2007). Leadership and organizational learning's role on innovation and performance: Lessons from Spain. Industrial Marketing Management, 36(3), 349-359.

Arbuckle, J. (2008). Amos 7.0 users guide, Springhouse, PA: AMOS Development Corporation.

Arham, A. (2014). The relationship between leadership behaviour, entrepreneurial orientation and organisational performance in Malaysian small and medium enterprises, Doctoral Dissertation, Royal Melbourne Institute of Technology.

Arham, A., Abu Hasan, H., Ridzuan, A., \& Sulaiman, N. (2015). The effect of leadership behaviours on entrepreneurial orientation: An online survey on Malaysian SMEs. International Journal of Latest Research in Science and Technology, 4(5), 47-50.

Association of Banks in Jordan (2015). The 36 annual report. Retrieve from 
http://www.abj.org.jo/ar-jo/annualreports.aspx [Accessed: 1st February 2016].

Banking Sector Report (2013). Jordanian banking sector brief 2013. Retrieve from http://www.awraq.com/uploads/research/308b6cf6089c8e03c9fc4f9b4a27573a053b3775.pdf

Banking Sector Report (2015). Jordanian banking sector brief 2015. Retrieve from http://www.awraq.com/uploads/research/8fd23684ebc8afe370812239063cbc26ee0bf5d9.pdf

Baron, R., \& Kenny, D. (1986). The moderator-mediator variable distinction in social psychological research: Conceptual, strategic, and statistical considerations. Journal of Personality and Social Psychology, 51(6).

Bass, B., \& Avolio, B. (1994). Multifactor leadership questionnaire. Palo Alto, CA: Consulting Psychologists Press.

Bell III, T., Anderson, T., Conner, C., \& Severance, J. (2016). Does leadership style affect the Academic performance of undergraduate business students? An empirical study. International Journal of Business \& Public Administration, 13(1), 112-125.

Boehm, S., Dwertmann, D., Bruch, H., \& Shamir, B. (2015). The missing link? Investigating organizational identity strength and transformational leadership climate as mechanisms that connect CEO charisma with firm performance. The Leadership Quarterly, 26, 156-171.

Chung-Wen, Y. (2008). The relationships among leadership styles, entrepreneurial orientation, and business performance. Managing Global Transitions, 6(3), 257-275.

Covin, J., \& Slevin, D. (1989). Strategic management of small firms in hostile and benign environments. Strategic Management Journal, 10, 75-87.

CSR Watch Jordan. (2014). Corporate responsibility in banking sector 2014. Retrieved from http://www.csrwatchjordan.com/uploads/1/5/6/2/15623468/corporate_responsibility_in_the_banking_sector _2014.pdf

Darawsheh, S., ALshaar, A., \& AL-Lozi, M. (2016). The degree of heads of departments at the University of Dammam to practice transformational leadership style from the point of view of the faculty members. Journal of Social Sciences (COES\&RJ-JSS), 5(1), 56-79.

Department of Statistics (2018). Gross domestic product (GDP) and economic indicators. Retrieve from http://dosweb.dos.gov.jo/industry/banks/

Dzomonda, O., Fatoki, O., \& Oni, O. (2017). The impact of leadership styles on the entrepreneurial orientation of small and medium enterprises in South Africa. Journal of Economics and Behavioral Studies, 9(2), 104-113.

Elshanti, M. (2017). Transformational leadership style and organizational learning: The mediate effect of organizational culture. International Business and Management, 15(2), 1-14.

García-Morales, V., Jiménez-Barrionuevo, M., \& Gutiérrez-Gutiérrez, L. (2012). Transformational leadership influence on organizational performance through organizational learning and innovation. Journal of Business Research, 65(7), 1040-1050.

García-Morales, V., Lloréns-Montes, F., \& Verdú-Jover, A. (2007). Influence of personal mastery on organizational performance through organizational learning and innovation in large firms and SMEs. Technovation, 27(9), 547-568.

Ghasemi, A., \& Zahediasl, S. (2012). Normality tests for statistical analysis: A guide for non-statisticians. International Journal of Endocrinology and Metabolism, 10(2), 486-489.

Ghorbanian, Z., Mo'meni, G., \& Ghorbanian, Z. (2016). The relationship between transformational leadership and organizational learning among high school principals in Isfahan. The Caspian Sea Journal, 10(1), 641-646.

Gomes, G., \& Wojahn, R. (2017). Organizational learning capability, innovation and performance: Study in small and medium-sized enterprises (SMES). Revista de Administração (São Paulo), 52(2), 163-175.

Hair, J., Black, W., Babin, B., Anderson, R., \& Tatham, R. (2010). Multivariate data analysis, 7th Edition, New York: Macmillion Publishing Company.

Hashim, A., Omar, C., Hamzah, M., \& Umar, A. (2018). Leadership behavior, entrepreneurial orientation and organizational performance. International Business Research, 11(9), 37-50. 
Hofstede, G. (2001). Culture's consequences. Thousand Oaks, CA, Sage.

Imamoglu, S., Ince, H., Keskin, H., Karakose, M., \& Gozukara, E. (2015). The role of leadership styles and organizational learning capability on firm performance. Journal of Global Strategic Management, 9(1), 113-124.

Imran, M., Ilyas, M., Aslam, U., \& Ubaid-Ur-Rahman. (2016). Organizational learning through transformational leadership. The Learning Organization, 23(4), 232-248.

Jerez-Gomez, P., Céspedes-Lorente, J., \& Valle-Cabrera, R. (2005). Organizational learning capability: A proposal of measurement. Journal of Business Research, 58(6), 715-725.

Judge, T., \& Piccolo, R. (2004). Transformational and transactional leadership: A meta-analytic test of their relative validity. Journal of Applied Psychology, 89(5), 755-768.

Karajeh, H., \& Maqableh, M. (2014). Security of cloud computing environment. The 23rd IBIMA Conference on Vision 2020: Sustainable Growth, Economic Development, and Global Competitiveness, USA, 2202-2215.

Kateb, M., Swies, R., Obeidat, B., \& Maqableh, M. (2015). An investigation on the critical factors of information system implementation in Jordanian information technology companies. European Journal of Business and Management, 7(36), 11-28.

Keskin, H. (2006). Market orientation, learning orientation, and innovation capabilities in SMEs: An extended model. European Journal of Innovation Management, 9(4), 396-417.

Khalayleh, W., Masa'deh, R., \& Al-Lozi, M. (2017). Administrative empowerment and its role on the work teams Performance: A literature review. Journal of Social Sciences (COES\&RJ-JSS), 6(4), 851-868.

Khwaldeh, S., Al-Hadid, I., Masa'deh, R., \& Alrowwad, A. (2017). The association between e-services web portals information quality and ICT competence in the Jordanian universities. Asian Social Science, 13(3), 156-169.

Kiziloglu, M. (2014). The effect of organizational learning on firm innovation capability: An investigation in the banking sector. Global Business and Management Research, 7(3), 17-33.

Kraus, S. (2013). The role of entrepreneurial orientation in service firms: Empirical evidence from Austria. The Service Industries Journal, 33(5), 427-444.

Lin, H., Zeng, S., Liu, H., \& Li, C. (2016). How do intermediaries drive corporate innovation? A moderated mediating examination. Journal of Business Research, 69(11), 4831-4836.

Madanchian, M., Hussein, N., Noordin, F., \& Taherdoost, H. (2016). The relationship between ethical leadership, leadership effectiveness and organizational performance: A review of literature in SMEs context. European Business \& Management, 2(2), 17-21.

Mahmood, R., \& Hanafi, N. (2013). Entrepreneurial orientation and business performance of women-owned small and medium entreprises in Malaysia: Competitive advantage as a mediator. International Journal of Business and Social Science, 4(1), 82-90.

Manshadi, M., Ebrahimi, F., \& Abdi, H. (2014). A study of the relationship between transformational leadership and organizational learning. European Journal of Experimental Biology, 4(1), 12-20.

Maqableh, M., \& Karajeh, H. (2014). Job scheduling for cloud computing using neural networks. Communications and Network, 6(3), 191-200.

Maqableh, M., Rajab, L., Quteshat, W., Khatib, T., \& Karajeh, H. (2015). The impact of social media networks websites usage on students' academic performance. Communications and Network, 7(4), 159-171.

Masa'deh, R. (2016). The role of knowledge management infrastructure in enhancing job satisfaction at Aqaba five star hotels in Jordan. Communications and Network, 8(4), 219-240.

Masa'deh, R., Alrowwad, A., Alkhalafat, F., Obeidat, O., \& Abualoush, S. (2018). The role of corporate social responsibility in enhancing firm performance from the perspective of IT employees in Jordanian banking sector: The mediating effect of transformational leadership. Modern Applied Science, 12(7), 1-26.

Masa'deh, R., Gharaibeh, A., Maqableh, M., \& Karajeh, H. (2013a). An empirical study of antecedents and outcomes of knowledge sharing capability in Jordanian telecommunication firms: A structural equation modeling approach. Life Science Journal, 10(4), 2284-2296.

Masa'deh, R., Hunaiti, Z., \& Bani Yaseen, A. (2008). An integrative model linking IT-business strategic 
alignment and firm performance: The mediating role of pursuing innovation and knowledge management strategies. Communications of the International Business Information Management Association (IBIMA) Journal.

Masa'deh, R., Obeidat, B., Zyod, D., \& Gharaibeh, A. (2015). The associations among transformational leadership, transactional leadership, knowledge sharing, job performance, and firm performance: A theoretical model. Journal of Social Sciences (COES\&RJ-JSS), 4(2), 848-866.

Masa'deh, R., Shannak, R., \& Maqableh, M. (2013b). A structural equation modeling approach for determining antecedents and outcomes of students' attitude toward mobile commerce adoption. Life Science Journal, 10(4), 2321-2333.

Menguc, B., Auh, S., \& Shih, E. (2007). Transformational leadership and market orientation: Implications for the implementation of competitive strategies and business unit performance. Journal of Business Research, 60(4), 314-321.

Mikkawi, B., \& Al-Lozi, M. (2017). The impact of knowledge management infrastructure on academic staff effectiveness: An empirical study at The University of Jordan. Jordan Journal of Business Administration, 13(1), 95-127.

Miller, D. (1983). The correlates of entrepreneurship in three types of firms. Management Science, 29(7), 770-791.

Muchiri, M., \& McMurray, A. (2015). Entrepreneurial orientation within small firms: A critical review of why leadership and contextual factors matter. Small Enterprise Research, 22(1), 17-31.

Muchran, B., \& Muchran, M. (2017). The influence of transformational leadership style to performance of Islamic bank with work motivation as a mediating variable. Review of European Studies, 9(2).

Nafei, W., Khanfar, N., \& Kaifi, B. (2012). Leadership styles and organizational learning: An empirical study on Saudi banks in Al-Taif governorate Kingdom of Saudi Arabia. Journal of Management and Strategy, 3(1), $2-17$.

Obeidat, B., Hadidi, A., \& Tarhini, A. (2017). Factors affecting strategy implementation: A case study of pharmaceutical companies in the Middle East. Review of International Business and Strategy, 27(3), 386-408.

Obeidat, B., Tarhini, A., \& Aqqad, N. (2017). The impact of intellectual capital on innovation via the mediating role of knowledge management: A structural equation modeling approach. International Journal of Knowledge Management Studies, 8(3/4), 273-298.

Öncer, A. (2013). Investigation of the effects of transactional and transformational leadership on entrepreneurial orientation. International Journal of Business and Social Research, 3(4), 153-166.

Radzi, C., Hui, H., Jenatabadi, H., Kasim, F., \& Radu, S. (2013). The relationship among transformational leadership, organizational learning, and organizational innovation: A case study in Asian manufacturing food industry. Asian Journal of Empirical Research, 3(8), 1051-1060.

Rajagopal, R. (2017). The mediating effect of organizational learning capability on high performance work system and corporate entrepreneurship relationship. Int'l Conf. on Law, Education, Business and Corporate Social Responsibilities (LEBCSR-17), Sept. 4-5, 2017 Budapest (Hungary).

Roomi, M., \& Harrison, P. (2011). Entrepreneurial leadership: What is it and how should it be taught?. International Review of Entrepreneurship, 9(3), 1-44.

Saunders, M., Lewis, P., \& Thornhill, A. (2012). Research methods for business students (6 Ed.), Pearson.

Sekaran, U., \& Bougie, R. (2016). Research methods for business: A skill building approach (7th Ed). John Wiley \& Sons.

Shannak, R., \& Obeidat, B. (2012). Culture and the implementation process of strategic decisions in Jordan. Journal of Management Research, 4(4), 257-281.

Tarhini, A., Alalwan, A., Al-Qirim, N., \& Algharabat, R. (2018). An analysis of the factors influencing the adoption of online shopping. International Journal of Technology Diffusion (IJTD), 9(3), 68-87.

Tarhini, A., Al-Badi, A., Almajali, M., \& Alrabayaah, S. (2017a). Factors influencing employees' intention to use cloud computing. Journal of Management and Strategy, 8(2), 47.

Tarhini, A., Al-Busaidi, K., Bany Mohammed, A., \& Maqableh, M. (2017b). Factors influencing students' 
adoption of e-learning: A structural equation modeling approach. Journal of International Education in Business, 10(2), 164-182.

Tarhini, A., Bany Mohammed, A., \& Maqableh, M. (2016). Modeling factors affecting student's usage behaviour of e-learning systems in Lebanon. International Journal of Business and Management, 11(2), 299.

Tarhini, A., Mgbemena, C., \& Trab, MSA. (2015). User adoption of online banking in Nigeria: A qualitative study. Journal of Internet Banking and Commerce, 20(3), 1-8.

Theriou, G., Theriou, N., \& Chatzoglou, P. (2007). The relationship between learning capability and organizational performance: The banking sector in Greece. Journal of Economics and Business, 57(2), 9-29.

Van-Wijk, E., \& Harrison, T. (2013). Managing ethical problems in qualitative research involving vulnerable populations, using a pilot study. International Journal of Qualitative Methods, 12(1), 570-586.

Vasconcelos, V., Silveira, A., \& Bizarrias, F. (2016). The relations between entrepreneurial orientation, organizational learning and organizational performance of small enterprises. International Journal of Professional Business Review, 1(2), 1-14.

West, S., Finch, J., \& Curran, P. (1995). Structural equation models with nonnormal variables: Problems and remedies. In: Hoyle RH, Editor. Structural Equation Modeling: Concepts, Issues and Applications. Newbery Park, CA: Sage, 56-75.

Wolff, J., Pett, T., \& Ring, J. (2015). Small firm growth as a function of both learning orientation and entrepreneurial orientation: An empirical analysis. International Journal of Entrepreneurial Behavior \& Research, 21(5), 709-730.

Yassien, E., \& Mufleh, M. (2017). The impact of ERP system's usability on enterprise resource planning project implementation success via the mediating role of user satisfaction. Journal of Management Research, 9(3), 49-71.

Zahra, S. (2010). Organizational learning and entrepreneurship in family firms: Exploring the moderating effect of ownership and cohesion. Small Business Economics, 38(1), 51-65.

\section{Copyrights}

Copyright for this article is retained by the author(s), with first publication rights granted to the journal.

This is an open-access article distributed under the terms and conditions of the Creative Commons Attribution license (http://creativecommons.org/licenses/by/4.0/). 